\title{
Low carbon heating and cooling of residential buildings in cities in the hot summer and cold winter zone - a bottom- up engineering stock modeling approach
}

Article

Accepted Version

Creative Commons: Attribution-Noncommercial-No Derivative Works 4.0

Li, X., Yao, R., Yu, W., Meng, X., Liu, M., Short, A. and Li, B. (2019) Low carbon heating and cooling of residential buildings in cities in the hot summer and cold winter zone - a bottom-up engineering stock modeling approach. Journal of Cleaner Production, 220. pp. 271-288. ISSN 0959-6526 doi: https://doi.org/10.1016/j.jclepro.2019.02.023 Available at https://centaur.reading.ac.uk/82294/

It is advisable to refer to the publisher's version if you intend to cite from the work. See Guidance on citing.

To link to this article DOI: http://dx.doi.org/10.1016/j.jclepro.2019.02.023

Publisher: Elsevier

All outputs in CentAUR are protected by Intellectual Property Rights law, including copyright law. Copyright and IPR is retained by the creators or other copyright holders. Terms and conditions for use of this material are defined in the End User Agreement. 


\section{www.reading.ac.uk/centaur}

\section{CentAUR}

Central Archive at the University of Reading

Reading's research outputs online 


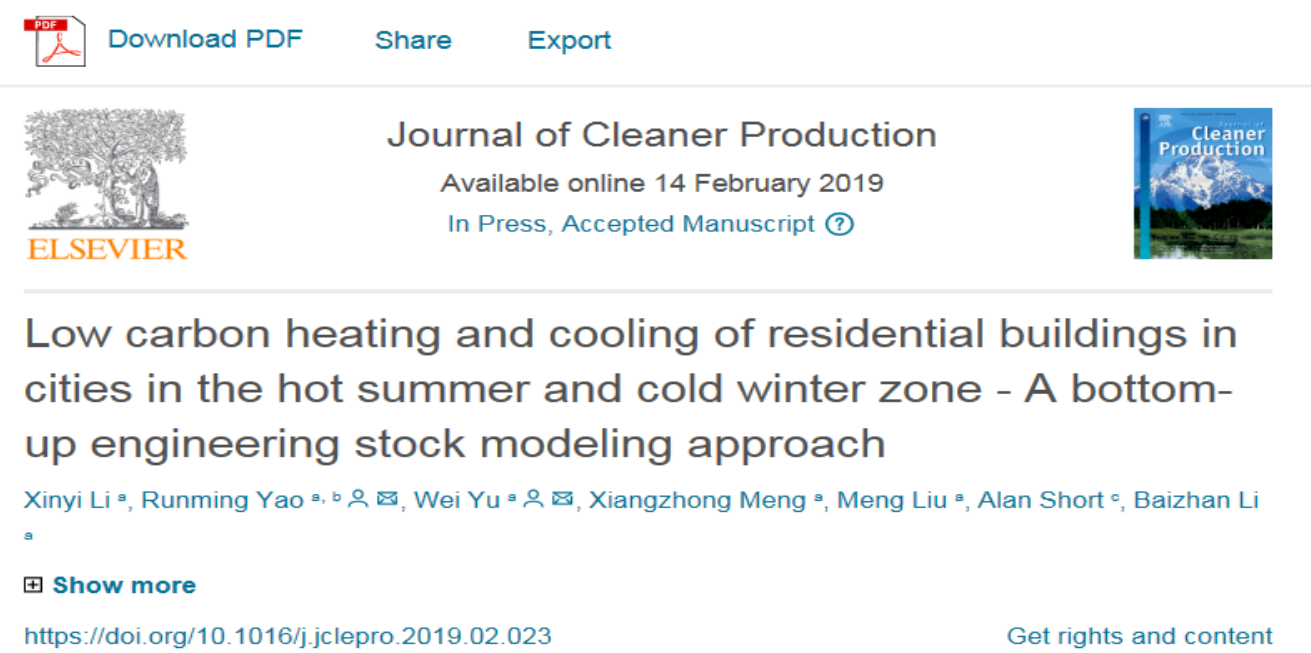

\title{
Low carbon heating and cooling of residential buildings in cities in the hot summer and cold winter zone - a bottom-up engineering stock modeling approach
}

Xinyi $\mathrm{Li}^{1}$, Runming $\mathrm{Yao}^{1,2^{*}}$, Wei $\mathrm{Yu}^{1 *}$, Xiangzhong Meng ${ }^{1}$, Meng $\mathrm{Liu}^{1}$, Alan Short ${ }^{3}$, Baizhan $\mathrm{Li}^{1}$

${ }^{1}$ Joint International Research Laboratory of Green Buildings and Built Environments (Ministry of Education), Chongqing University, Chongqing, China

${ }^{2}$ School of the Built Environment, University of Reading, RG6 6DF, Reading, UK

${ }^{3}$ Department of Architecture, University of Cambridge, CB2 1PX, Cambridge, UK

Corresponding author email: r.yao@reading.ac.uk; r.yao@cqu.edu.cn; yuweixscq@126.com

https://doi.org/10.1016/j.jclepro.2019.02.023

\begin{abstract}
Building stock modeling can predict stock energy consumption and carbon emissions for both current and future conditions to inform building design and retrofitting policies. A 'bottom-up' engineering approach for building stock energy modeling is attractive to built environment energy researchers because of its capacity for detailed energy analysis. However, such studies in China have been very limited to date. The aim of this research is to develop a modeling approach to residential building stock energy consumption for space heating and cooling. A holistic four-step approach of archetype configurations; building performance simulation; stock floor area estimation and local weather adjustment is presented. The Chongqing municipality was chosen to demonstrate the approach. The results show that adopting the northern China standard
\end{abstract}


pattern of central space heating for Chongqing's urban residential stock is not feasible because it dramatically increases primary energy consumption and therefore carbon dioxide emissions from space heating usage. By applying energy conservation retrofit measures to the Chongqing urban residential stock, the total energy consumption for space heating and cooling and resulting carbon dioxide emissions can be significantly reduced, with estimated reductions of $57.6 \%$ to $60.7 \%$ in 2020 and $55.3 \%$ to $57.2 \%$ in 2050. The method described can provide useful information and guidance for policymakers contemplating energy retrofit schemes.

-Keywords: residential buildings, space heating and cooling, bottom-up engineering model, building stock, energy consumption, future climate

\section{Introduction}

Largely driven by economic and population growth, greenhouse gas emissions have increased to an historical peak with the accumulation of carbon dioxide emissions believed to be instrumental in determining global mean surface warming (IPCC, 2014). China is responsible for $20.4 \%$ of global total final energy consumption (IEA, 2017). As the largest emitter of carbon dioxide, China contributes $30 \%$ of global $\mathrm{CO}_{2}$ emissions from fossil fuel combustion, cement manufacture and gas flaring processes (EPA, 2017). According to the Chinese Building Energy Model developed by THUBERC (THUBERC, 2017) in 2015, operational energy consumption for Chinese buildings accounts for $20 \%$ of national total energy consumption and emissions of 2.22 Billion tons of $\mathrm{CO}_{2}$. As China aims to lower carbon dioxide emissions per unit of GDP by between 60\% and 65\% of the 2005 level by 2030 (Department of Climate Change, 2015), the Chinese government is paying great attention to low-carbon development (State Council, 2016). Cities are recorded as contributing $70 \%$ of the world's energy-related greenhouse gases (Baeumler et al., 2012) and are therefore a very important focus for carbon dioxide emission reduction (Shen et al., 2018). The Chinese government has been promoting low carbon cities since 2010, with Chongqing nominated as one of the pilot cities (National Development and Reform Commission, 2010).

Residential building stock, including both urban and rural, accounted for $58.5 \%$ of the total built floor area in China while consuming $48 \%$ of the energy used in Chinese buildings (THUBERC, 2017). This gives them an important potential role in controlling energy consumption and carbon emissions. China's $13^{\text {th }}$ Five Year Plan (2016-2020) sets the following goals for energy conservation in residential buildings: 1) to achieve the energy efficient refurbishment of more than 5 billion $\mathrm{m}^{2}$ of residential floor area, and 2) to make at least $60 \%$ of the residential building stock, energy efficient (MOHURD, 2017; SCC, 2016). 
Energy consumption for space heating and cooling accounts for 58\% of urban household energy consumption in China (Zheng et al., 2014). This is comparable to levels in Western developed countries (the United States, 48\% (EIA, 2013), the United Kingdom 70\% (Department for Business Energy \& Industrial Strategy, 2017), and the European Union 65\% (Eurostat, 2018)). However, the absolute value of current residential space heating and cooling energy consumption in China is still relatively much lower (Zheng et al., 2014).

The Hot Summer and Cold Winter (HSCW) zone, located in southern China, covers 16 provinces. It is a densely populated region and delivers $48 \%$ of the gross domestic product of China (Xu et al., 2013). The current indoor environment in the HSCW zone is relatively poor (Yao et al., 2018), with indoor temperatures of over $30^{\circ} \mathrm{C}$ in summer and below $15^{\circ} \mathrm{C}$ in winter ( $\mathrm{Li}$ and Yao, 2012; Li et al., 2014). Due to the thriving economy and increasing incomes, occupants' thermal comfort requirements are also improving (Gui et al., 2018; Liu and Kojima, 2017; Liu et al., 2017). The improved comfort requirements potentially lead to an increasing need for energy for space heating and cooling, which places tremendous pressure on the national energy saving and carbon reduction target.

The Chinese government is particularly concerned with residential energy consumption in the hot summer and cold winter zone, through design standard implementation (MOHURD, 2001, 2010) and policy guidance (MOHURD, 2012a, 2017). The HSCW residential stock at the conclusion of the $12^{\text {th }}$ Five-year plan, including all newly constructed residential buildings, has achieved the latest energy efficiency design standard. 70.9 million $\mathrm{m}^{2}$ of residential building has undergone the retrofit process, 1.42 times the original Government Ministry's target (MOHURD, 2017).

However, the energy conservation and carbon reduction impacts of different energy efficiency measures are still unclear at the larger scale of a city or town. There is an urgent need to understand the current energy consumption of the existing building stock and to have a reliable projection of the future situation in order to guarantee effective energy conservation instruction within a city. But, due to the historical system of collecting statistical data relating solely to industrial categories in China, no official statistical data exists for the operational energy consumption of residential buildings (CABEE, 2016). The energy consumption of different end-uses, including space heating and cooling, is also unavailable. Although nationwide residential stock survey data, like the US Residential Energy Consumption Survey (RECS) data (EIA, 2017), would be very useful for giving an insight into real stock energy consumption, this kind of national scale residential stock official survey does not exist in China yet. Zheng et al. (2014) conducted a comprehensive survey of residential energy consumption in China for 2012. Their survey sample (1450 households in 26 Chinese provinces) is rather limited and maybe not fully representative of the entire Chinese residential stock. 
There are privacy issues related to the collection of residential energy consumption data in China. Building stock modeling presents an alternative option to a full large-scale survey to investigate Chinese residential building energy consumption.

\subsection{Building stock energy modeling}

Building stock energy modeling is a method of depicting current stock energy consumption and predicting its future evolution (Reinhart and Davila, 2016). Broadly, building stock energy consumption models can be divided into two types based on the modeling approach, namely top-down and bottom-up (Kavgic et al., 2010; Swan and Ugursal, 2009). The top-down approach, including econometric and technological topdown models, uses regression to find the relationship between building stock energy consumption and top-level variables like macroeconomic indicators, the energy price, and general climate. The bottom-up approach, including statistical and engineering bottom-up models, determines the energy consumption of every building within the study area before aggregated this data to get the stock energy consumption. The topdown approach can account for macroeconomic and socioeconomic effects and the toplevel variables are easier to obtain, but it relies on historical consumption information. Technical detail cannot be added to the model. However, the bottom-up approach can evaluate the impact of energy conservation measures on the stock as a whole, but it needs extensive databases containing detailed building characteristics or energy consumption. Detailed benefits and limitations of the bottom-up and top-down building stock modeling approaches can be found in Kavgic et al. (2010) and Swan and Ugursal (2009). Within the bottom-up approach, the bottom-up statistical model relies heavily on a historical energy consumption dataset and tries to find the relationship between the building energy consumption and building features. The prerequisite of using the bottom-up statistical model is the real measured energy consumption of the building stock, which is usually unavailable in China. However, the bottom-up engineering model is based on the building heat balance calculations which provide a "ground-up" energy estimation. Moreover, the bottom-up engineering model provides the maximum flexibility for testing energy conservation measures in detail and determining building energy end-use distribution. It has been classified as a white-box based approach utilizing a detailed thermal physics simulation (Tardioli et al., 2015).

Bottom-up engineering building stock energy modeling can assess stock end-use energy consumption in detail and stock energy consumptions under changing stock conditions (i.e. when energy conservation technologies are applied) (Kavgic et al., 2010; Swan and Ugursal, 2009). Residential stock bottom-up engineering modeling has been applied in EU states (Ballarini et al., 2014; Caputo et al., 2013; Dascalaki et al., 2011; Filogamo et al., 2014; Heeren et al., 2013; Kragh and Wittchen, 2014; Mastrucci et al., 2017; Monteiro et al., 2017; TABULA, 2016); in Japan (Shimoda et al., 2007; Shimoda et al., 2004; Shimoda et al., 2010); in the UK (Cheng and Steemers, 2011; Firth et al., 
2010); in the USA (Cerezo Davila et al., 2016; Sokol et al., 2017; Wilson et al., 2016) and in China (An et al., 2017; Wang et al., 2015).

For the Chinese context, An et al. (2017) set up a small scale but encouraging stock cooling energy need model for a community and obtained a result closely matching the measured data. Wang et al. (2015) developed a Residential Heating Energy Model (RHEM) for studying current residential heating energy consumption in China's HSCW zone. However, such studies in China did not consider both space heating and cooling energy consumption. Future energy consumption under both climate change and stock variation are not considered. Nor did the existing studies analyze the potential future stock level total energy conservation performance of different retrofit measures. Therefore, this study attempts to cover those gaps and build a bottom-up residential stock energy model capable of calculating current and future space heating and cooling energy consumption as well as the evaluation of stock level total energy conservation performance provided by the different retrofit measures considered.

\subsection{Building archetypes}

The archetype approach aims at defining typical buildings that represent the studied stock(Li et al., 2018) widely applied in residential building bottom-up engineering modeling. The main selected archetype classification indices include household categories (Shimoda et al., 2007; Shimoda et al., 2004; Shimoda et al., 2010; Wang et al., 2015); built form (An et al., 2017; Ballarini et al., 2014; Caputo et al., 2013; Cheng and Steemers, 2011; Dascalaki et al., 2011; Filogamo et al., 2014; Firth et al., 2010; Kragh and Wittchen, 2014; Mastrucci et al., 2017; Monteiro et al., 2017; Shimoda et al., 2007; Shimoda et al., 2004; Shimoda et al., 2010; TABULA, 2016; Wilson et al., 2016), construction age (Ballarini et al., 2014; Caputo et al., 2013; Cerezo Davila et al., 2016; Cheng and Steemers, 2011; Dascalaki et al., 2011; Filogamo et al., 2014; Firth et al., 2010; Heeren et al., 2013; Kragh and Wittchen, 2014; Mastrucci et al., 2017; Monteiro et al., 2017; Sokol et al., 2017; TABULA, 2016; Wilson et al., 2016), a building's physical construction (Monteiro et al., 2017; Wilson et al., 2016) and a building's technical system (Heeren et al., 2013; Sokol et al., 2017; Wilson et al., 2016).

\subsection{The aim and scope}

The aim of this research is to develop a localized residential building stock space heating and cooling modeling approach to estimate energy consumption and related carbon emissions. As building construction and technical systems are commonly closely connected with building construction age, in this study only household categories, built form and construction age are selected as key indices for archetype development. The developed modelling approach is expected not only to be able back- 
estimate historical energy consumption and carbon emission, but also to project future scenarios under stock variation and climate change. Moreover, this approach provides the method of analyzing energy conservation performance of difference retrofit measures for the future building stock. The methodology of the proposed modeling approach is suitable to any other cities.

The utilitilisation of the model for decision-making is explored by testing different stock retrofit measures for Chongqing municipality.

\section{Methodology}

The fundamental information required by this approach is the classification of archetypes available through national statistical data. Building simulations for each archetype are then performed and aggregated to construct the stock model. Methodologically, residential building stock energy modelling is a four step process as shown in Figure 1:

Step 1: Develop residential archetypes. Based on household categories, built form and the construction age of the residential stock under investigation, identify typical archetypes to represent the residential stock;

Step 2: Space heating and cooling energy consumption simulation and aggregation. Utilize computer simulation techniques to calculate space heating and cooling energy consumption (more specifically, energy use intensity) for different residential archetypes, aggregate the average energy use intensity and carbon dioxide emissions for residential buildings of different construction age ranges;

Step 3: Stock total floor area calculation and construction age distribution. Calculate the total floor area of the studied stock and make projections about the possible future scenarios, assign the floor area into different construction age groups considering both the new construction and old building demolition;

Step 4: Weather-adjusted stock space heating and cooling energy consumption. Collect past real weather data and generate "business as usual" future weather via the climate change world weather file generator (SERG, 2017). Calculate heating and cooling degree-days to refine the estimation of space heating and cooling energy consumption of the studied stock for both past and future time points under different scenarios. Convert space heating and cooling energy consumption into carbon dioxide emissions using $\mathrm{CO}_{2}$ emission factors. 


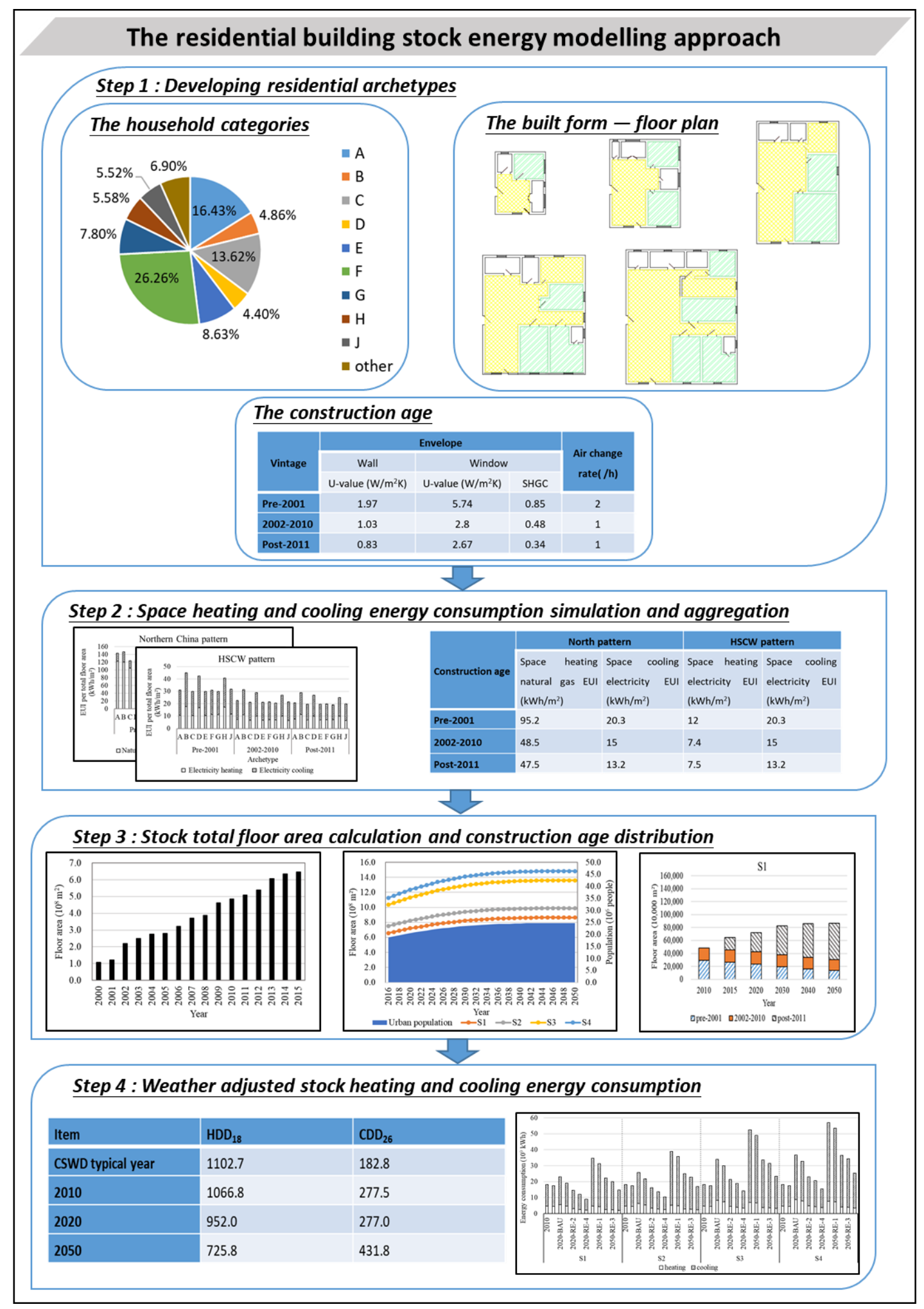

Figure 1: Research Framework

The Chongqing municipality has a population of over 30 million people located in the southwest of China covering an area of $82,400 \mathrm{~km}^{2}$ (State Council, 2017) with an urbanization rate of $60.9 \%$ (Chongqing Minicipal Bureau of Statistics \& NBS Survey Office in Chongqing, 2016). Urban residential buildings floor area accounts for over 
$65 \%$ of the total residential floor area in Chongqing (Chongqing Statistics Bureau, 2016). A case study of Chongqing city has been conducted to demonstrate the application of the proposed approach.

\section{Residential archetypes}

\subsection{The household categories}

The household categories provided information about numbers of family members and numbers of generations for an individual family. From the most up-to-date 2010 census data (Chongqing Statistics Bureau, 2012), less than 3\% of all households have six or more people, so this minor household category may be ignored. Hence, the maximum number of people in a household was selected as five. The information on the number of generations was used to give an insight into household structures. For example, households with three or above generations will have elderly people at home. Census data (Chongqing Statistics Bureau, 2012) about households with elderly members (aged 60 and over) has been utilized to obtain a much finer classification of household structures. Age 60 is the highest retirement age for Chinese citizens, so people at or above 60 years old are retired. Households with one elderly retiree and elderly retired couples accounted for $4.86 \%$ and $4.40 \%$ of all households respectively. The selected representative household structures and their corresponding percentage for each household category are listed in Table 1 . Thus, 93\% of all household categories have been covered in the selected representative household structures, so it is justifiable to say this stock model is likely to be adequate to cover Chongqing's urban residential households.

Table 1: The household structure distribution of the Chongqing urban area

\begin{tabular}{lllll}
\hline $\begin{array}{l}\text { Household } \\
\text { categories }\end{array}$ & $\begin{array}{l}\text { Number of } \\
\text { generations }\end{array}$ & $\begin{array}{l}\text { Number of } \\
\text { people in a } \\
\text { household }\end{array}$ & Household structure & $\begin{array}{c}\text { Percentage of } \\
\text { households }\end{array}$ \\
\hline A & 1 & 1 & One working & $16.43 \%$ \\
B & 1 & 1 & One retired & $4.86 \%$ \\
C & 1 & 2 & Two working [couple] & $13.62 \%$ \\
D & 1 & 2 & Two retired [couple] & $4.40 \%$ \\
E & 2 & 2 & $\begin{array}{l}\text { One working single }+ \\
\text { one juvenile }\end{array}$ & $8.63 \%$ \\
F & 2 & 3 & $\begin{array}{l}\text { Two working [couple] } \\
+ \text { one juvenile }\end{array}$ & $26.26 \%$ \\
\hline & & & & \\
\hline
\end{tabular}




\begin{tabular}{|c|c|c|c|c|}
\hline $\mathrm{G}$ & 2 & 4 & $\begin{array}{l}\text { Two working [couple] } \\
+ \text { two juveniles }\end{array}$ & $7.80 \%$ \\
\hline $\mathrm{H}$ & 3 & 4 & $\begin{array}{l}\text { One retired single + two } \\
\text { working [couple] + one } \\
\text { juvenile }\end{array}$ & $5.58 \%$ \\
\hline $\mathbf{J}$ & 3 & 5 & $\begin{array}{l}\text { Two retired [couple] }+ \\
\text { two working [couple] }+ \\
\text { one juvenile }\end{array}$ & $5.52 \%$ \\
\hline
\end{tabular}

The family structure influences the occupancy period because the working occupants will be at work during working hours while the retired occupants are more likely to spend more time at home. The duration of household occupation influences heating and cooling energy consumption dramatically since the most common usage mode in China for space heating and cooling is part time for partial space (Hu et al., 2017), which means that only occupied space will be heated or cooled.

\subsection{The built form}

As the multifamily residential building dominates the Chinese residential stock (Yu et al., 2014b), the built form of Chongqing urban residential building is based on the individual household flat. The residential floor area per capita for Chongqing urban residents is $35 \mathrm{~m}^{2}$ (Chongqing Minicipal Bureau of Statistics \& NBS Survey Office in Chongqing, 2016). The total floor area for each household category was determined using equation 1 .

$\mathrm{F}=\mathrm{f} \times \mathrm{P}$

Where $\mathrm{F}$ is the total floor area of the household/studied stock $\left(\mathrm{m}^{2}\right), \mathrm{f}$ is the residential floor area per capita $\left(\mathrm{m}^{2}\right)$ and $\mathrm{P}$ is the total number of people in the household/studied stock.

As most Chinese residential buildings are of rectangular shape (Qi and Wang, 2014), the floor plans assumed for the different household categories are also rectangular, referencing actual extant floor plan design drawings collected from across the Chongqing urban residential estate market. The floor area for each individual room was checked against the minimum area requirements of the Chinese residential building design code (MOHURD, 2011). The detailed information for the selected typical floor plan types, including total floor area and its corresponding household categories, is shown in Table 2.

Table 2: Floor plans. The areas covered in a cross hatch pattern and cross pattern are 
bedrooms and activity areas respectively, while blank areas are kitchen, storage rooms and toilets.

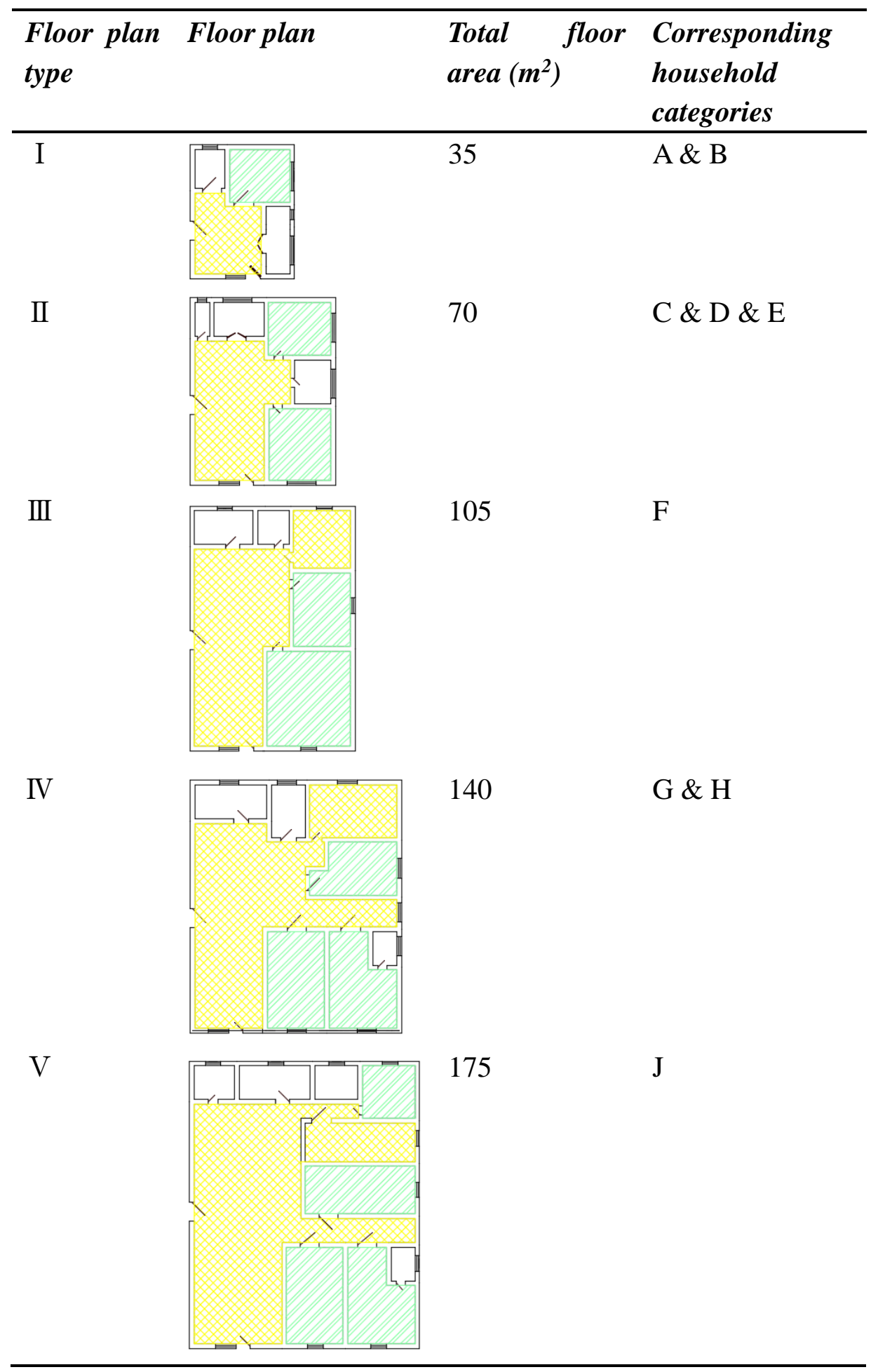

The 'typical' household was assumed to be located on a middle floor; each with three external walls and one internal wall within which the entrance door is located. Windowto-wall ratios are set as $0.45,0.35$ and 0.4 for south, east and north external walls respectively (MOHURD, 2010). To simplify the simulation, the internal surfaces, 
including floor, ceiling, and interior walls were assumed to be adiabatic. This represents the situation where space heating and cooling behavior and the thermal preferences of neighboring households are similar, with very similar indoor temperatures.

\subsection{The construction age}

The first energy efficiency design standard for residential buildings in the hot summer and cold winter zone, JGJ 134-2001, came into force in October 2001(MOHURD, 2001). An updated revised version [JGJ 134-2010] was activated from August 2010 (MOHURD, 2010). The construction age band classification for residential buildings is based on the sequence of improving standards. Three age bands were defined, namely pre-2001 (included 2001), 2002-2010 (included 2010), and post-2011 (included 2011) enabling the envelope thermophysical characteristics of residential buildings in different construction age bands to be defined. Detailed information is presented in Table 3.

Table 3: Residential building envelope characteristics (MOHURD, 2001, 2010)

\begin{tabular}{lcccc}
\hline & \multicolumn{3}{c}{ Envelope } & Air \\
Vintage & $\begin{array}{c}\text { Wall } \\
\text { U-value } \\
\text { (W/m2K) }\end{array}$ & U-value $(\mathrm{W} / \mathrm{m} 2 \mathrm{~K})$ & $\begin{array}{c}\text { Solar heat gain } \\
\text { coefficient }\end{array}$ & $\begin{array}{c}\text { change } \\
\text { rate( } / \boldsymbol{h})\end{array}$ \\
\hline $\begin{array}{l}\text { Pre- } \\
2001\end{array}$ & 1.97 & 5.74 & 0.85 & 2 \\
$2002-$ & 1.03 & 2.80 & 0.48 & 1 \\
2010 & 0.83 & 2.67 & & 1 \\
$\begin{array}{l}\text { Post- } \\
2011\end{array}$ & & & 0.34 & 1 \\
\hline
\end{tabular}

After considering nine typical household categories, assigning an appropriate built form for each of the household categories and considering three different construction ages, 27 residential archetypes have been generated in this section.

\section{Energy simulation and aggregation}

In this study, EnergyPlus (version 8.8.0) is employed to model building space heating and cooling energy consumption. EnergyPlus (DOE, 2017), the building energy simulation program developed by the United States Department of Energy, is the stateof-art building simulation program and had been listed in the IBPSA building energy software tools list (IBPSA, 2018). A series of analytical tests, comparative tests as well as release and executable tests had been conducted to validate EnergyPlus simulation results (DOE, 2018). Therefore, EnergyPlus had already been extensively utilized for 
building energy related studies (Ahn et al., 2017; Chen et al., 2017; Xu et al., 2015; Yao et al., 2018; Yi et al., 2015).

\subsection{The verification of the energy modelling}

To ensure the accuracy and reliability of the application of the EnergyPlus simulation , a comparisons of the measured and simulated free running indoor air and the surface temperatures had been carried out for six days from $7^{\text {th }}$ to $13^{\text {th }}$ April, 2017. The test room is located in the $3^{\text {rd }}$ floor of a ten-floor residential building. The outlook of the building as well as the floor plan of the test room is shown in

Figure 2.
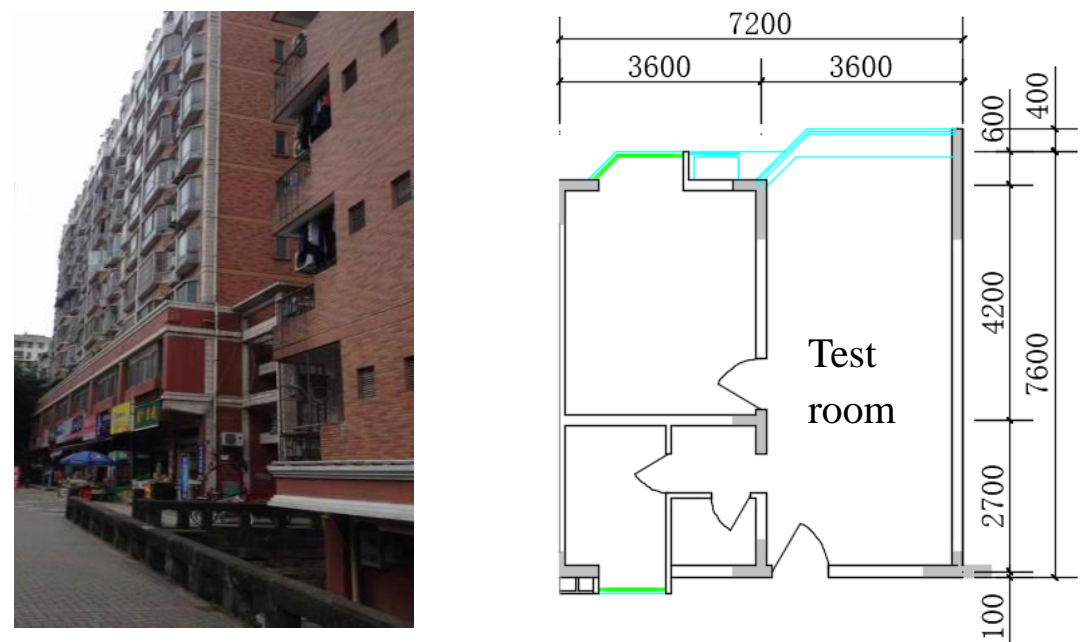

Figure 2: The outlook of the building (left) and the floor plan of the test room (right)

The indoor air temperature and external wall surfaces temperature had been measured in the test room. By referencing related Chinese standards GB/T 507852012(MOHURD, 2012b) and JGJT 132-2009(MOHURD, 2009), the layout of the measurement points are shown in Figure 3 and Figure 4. The instruments used for indoor air temperature measurement are HOBO UX100-003 Temp/RH and Telaire TEL-7001, whilst K type thermocouples are used for surface temperature monitoring. Considering the real situation of a fire-hydrant cabinet located in the middle of the external surface of external wall, the layout of external wall surface temperature measuring points had been equally considered for the whole six measurement days. 




Figure 3: The layout of indoor air temperature measuring points

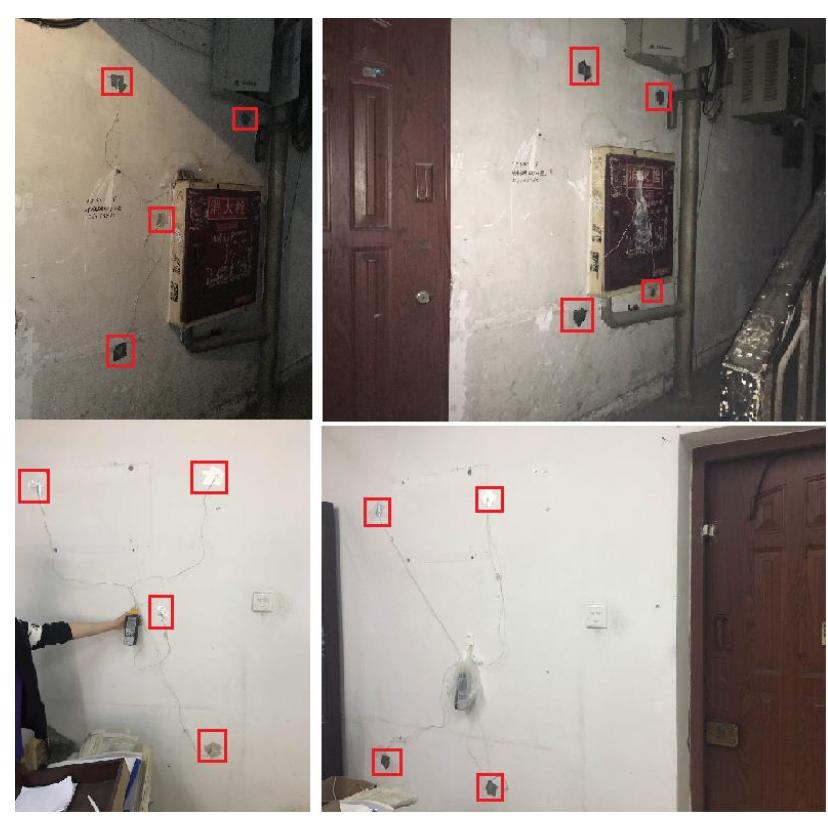

Figure 4: The layout of external wall surface temperature measuring points (external surface (top), internal surface (bottom)

The building physical model had been generated (shown in Figure 5) for the simulation using EnergyPlus. During the test period, the test room is unoccupied with no lighting and equipment in operation. The internal load of the test room had been set as none.

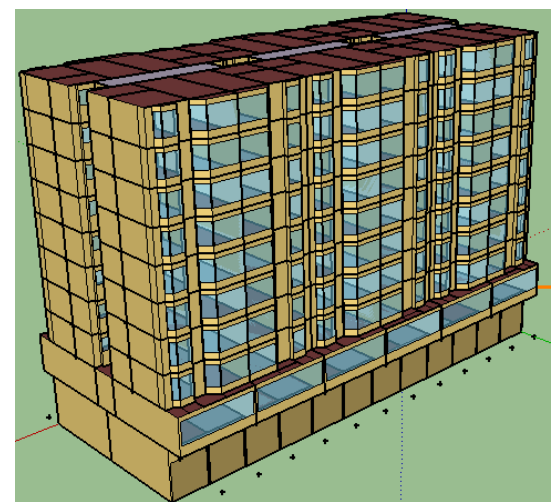

Figure 5: Building physical model 
The local weather condition from a nearby outdoor weather station (Davis Vantage Pro2) had been used in the simulation. To quantify the difference between the values of the simulated and the measured, two dimensionless error indexes had been used, namely Mean Bias Error (MBE) and Coefficient of Variation of the Root Mean Square Error (CV(RMSE)) using equation 2 and equation 3 respectively (Royapoor and Roskilly, 2015),

$\operatorname{MBE}=\frac{\sum_{i=1}^{N_{i}}\left(M_{i}-S_{i}\right)}{\sum_{i=1}^{N_{i}} M_{i}}$

$\mathrm{CV}(\mathrm{RMSE})=\frac{\sqrt{\sum_{i=1}^{N_{i}}\left[\frac{\left(M_{i}-S_{i}\right)^{2}}{N_{i}}\right]}}{\frac{1}{N_{i}} \sum_{i=1}^{N_{i}} M_{i}}$

Where, $\mathrm{M}_{\mathrm{i}}$ is the measured value corresponding to time $\mathrm{i}\left({ }^{\circ} \mathrm{C}\right) ; \mathrm{S}_{\mathrm{i}}$ is the simulated value corresponding to time $\mathrm{i}\left({ }^{\circ} \mathrm{C}\right) ; \mathrm{N}_{\mathrm{i}}$ is the total number of values used in the calculation.

The MBE and CV(RMSE) between hourly simulation and measurement values for indoor air temperature, external wall external surface temperature and external wall internal surface temperature are calculated and shown in

Table 4. The MBEs are negative, which means the measured value is more likely to be smaller than the simulation value, but all MBEs are within - 5\%, and the CV(RMSE) is within $10 \%$. It shows that the deviations between simulated and measured values are small. This demonstrates the satisfactory of the application of the EnergyPlus software in this research.

Table 4: MBE and CV(RMSE) between simulation and measurement

\begin{tabular}{lll}
\hline Items & MBE & CV(RMSE) \\
\hline Indoor air temperature & $-4.5 \%$ & $7.8 \%$ \\
External wall external surface temperature & $-3.9 \%$ & $9.0 \%$ \\
External wall internal surface temperature & $-4.4 \%$ & $6.4 \%$ \\
\hline
\end{tabular}

\subsection{Energy use intensity for different residential archetypes}

Historically, the Chinese government set north-south dividing Qin-Huai line with district heating only available to the north. As southern China is cold and humid in winter, southern people, especially people living in the HSCW zone, are interested in installing district heating systems (China Daily, 2013; People's Daily, 2013). But the deployment of district heating in the HSCW zone will increase dramatically so that the 
space-heating-related energy consumption would become equal to the entirety of the electricity produced by two Three Gorges Project hydroelectric power stations (Guo et al., 2015). The impact of adopting northern China type district heating in the Chongqing urban residential stock is evaluated using the bottom-up model.

Chinese Standard Weather Data (CSWD) for Chongqing Shapingba, downloaded from the EnergyPlus website, is used in the simulation as the typical climate condition. For internal loads, the lighting density of residential building is defined as $6 \mathrm{~W} / \mathrm{m}^{2}$ (MOHURD, 2013b) and the equipment density is defined as $4.3 \mathrm{~W} / \mathrm{m}^{2}$. Occupancy patterns defined in the Residential Heating Energy Modeling (RHEM) for the HSCW zone (Wang et al., 2015) have been utilized in this study (shown in Table 5), with both the common work shift timetable as well as the sleeping habits of residents being taken into consideration. Lighting is turned on after 17:00 if occupied by an awake occupant and equipment is operated when the room is occupied by an awake occupant.

Table 5: Occupancy patterns of different room types (Wang et al., 2015)

Unoccupied $(U)$, occupied with occupant $(s)$ awake $(O . W)$, occupied with occupant(s) asleep (O.S).

Room type

$$
0: 00-\quad 8: 00-\quad 12: 30-\quad 14: 00-\quad 17: 00-\quad 22: 00-
$$

$$
8: 00 \quad 12: 30 \quad 14: 00 \quad 17: 00 \quad 22: 00 \quad 24: 00
$$

\begin{tabular}{lllllll}
\hline $\begin{array}{l}\text { Retired people's } \\
\text { bedroom }\end{array}$ & $\mathrm{O} . \mathrm{S}$ & $\mathrm{U}$ & $\mathrm{O} . \mathrm{S}$ & $\mathrm{U}$ & $\mathrm{U}$ & $\mathrm{O} . \mathrm{W}$ \\
$\begin{array}{l}\text { Working/school } \\
\text { people bedroom }\end{array}$ & $\mathrm{O} . \mathrm{S}$ & $\mathrm{U}$ & $\mathrm{U}$ & $\mathrm{U}$ & $\mathrm{U}$ & $\mathrm{O} . \mathrm{W}$ \\
$\begin{array}{l}\text { Retired people } \\
\text { activity area }\end{array}$ & $\mathrm{U}$ & $\mathrm{O} . \mathrm{W}$ & $\mathrm{U}$ & $\mathrm{U}$ & $\mathrm{O} . \mathrm{W}$ & $\mathrm{U}$ \\
$\begin{array}{l}\text { Working/school } \\
\text { people activity area }\end{array}$ & $\mathrm{U}$ & $\mathrm{U}$ & $\mathrm{U}$ & $\mathrm{U}$ & $\mathrm{O} . \mathrm{W}$ & $\mathrm{U}$ \\
\hline
\end{tabular}

Air conditioning units with a cooling coefficient of 2.3 (MOHURD, 2001, 2010) are used for space cooling. The cooling calculation period for Chongqing residential households was taken as $1^{\text {st }}$ June to $30^{\text {th }}$ September, with a cooling set point of $26^{\circ} \mathrm{C}$ (Chongqing municipal commission of urban-rural development, 2016). The authors assumed that only activity areas (including the living room and study) and bedrooms are cooled. As occupants only stay in the auxiliary areas (including the toilet, storage room and kitchen) for a limited amount of time, it is normally not cooled. Cooling is made available whenever the room is occupied during the set period.

For space heating, the heating calculation period for Chongqing residential households 
was assumed to be from $1^{\text {st }}$ December to $28^{\text {th }}$ February, with a heating set point of $18^{\circ} \mathrm{C}$ (Chongqing municipal commission of urban-rural development, 2016). Two different space-heating patterns were considered, as follows:

1) The northern China heating pattern: As the space heating pattern for district heating in China is continuous, with full space heating through the heating period(Wei et al., 2014). In the scenario in which district heating is made available in Chongqing, the space heating pattern will very likely change to full time-full space (continuous space heating supply for all rooms during the heating periods). Gas boilers, coal boilers, as well as Combined Heat and Power plants (CHP) are the main heat sources in northern China district heating (THUBERC, 2015). The heat source for Chongqing urban residential buildings is assumed to be a gas boiler because the Chongqing government actively promotes gas boilers instead of coal boilers (CQMPG, 2016). The gas boiler efficiency for heating supply is assumed as being 90\% (THUBERC, 2016).

2) The HSCW heating pattern: Heat pump air conditioning units, the most commonly used space heating and cooling integrated terminal in residential buildings within the HSCW zone (THUBERC, 2017), are assumed to provide the space heating supply. The heating coefficient of the split unit is assumed to be 1.9 (MOHURD, 2001, 2010) acknowledging that some households are using electric heaters for heating in winter. As the current space heating usage pattern is part time - part space (THUBERC, 2017), only occupied activity areas (including the living room and study) and bedrooms are space heated. Moreover, heating is assumed to be available only when the occupants of the room are actually awake. As survey results from Wang et al. (2015) suggest, the majority of HSCW residents turn the heating off before retiring to sleep. This represents the current situation in the HSCW zone.

The space heating and cooling EUIs per building floor area for each residential archetype under two different heating patterns are shown in Figure 6. 



Figure 6: The space heating and cooling energy use intensities for every archetype of Chongqing urban residential stock under the different heating scenarios: Northern China (top) and HSCW (bottom) pattern

4.3 The average heating and cooling energy use intensity of the different construction age groups

Space heating and cooling energy use is known to diversify across the different archetypes. Establishing the average space heating and cooling energy use intensity of the different construction age groups requires the floor area percentage of every household category in the whole stock, which is calculated using the following equation 4 , 


$$
F H P_{y}=N H P_{y} \times F_{y} / \sum\left(N H P_{y} \times F_{y}\right)
$$

Where $\mathrm{FHP}_{\mathrm{y}}$ is the floor area percentage of household type $\mathrm{y}$; $\mathrm{NHP}_{\mathrm{y}}$ is the household percentage of household category $y$; $F_{y}$ is the total floor area of the floor plan corresponding to household category $\mathrm{y} ; \mathrm{y}$ is the household category index, including the nine categories A, B, C, D, E, F, G, H and J. The floor area percentage of every household category in the stock is shown in Figure 7, the type F households accounted for the highest total floor area (34\%), while type B households occupy only $2 \%$ of the total floor area.

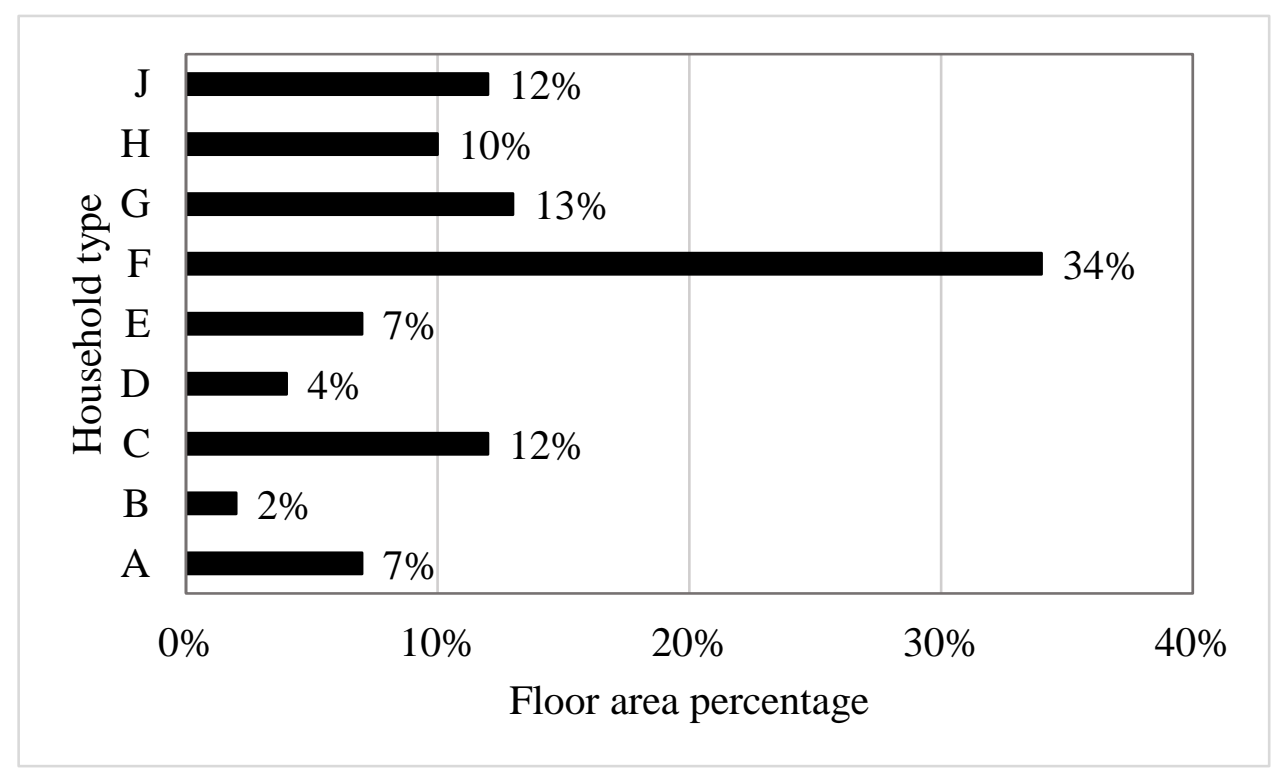

Figure 7: Floor area percentage of every household category within the Chongqing urban residential stock.

The average space heating and cooling EUIs for households at each construction age were calculated considering the floor area percentage for every household category using the following equations 5-6,

$\operatorname{HAEUI}_{x}=\sum H E U I_{x, y} \times F H P_{y}$

$\mathrm{CAEUI}_{x}=\sum C E U I_{x, y} \times F H P_{y}$

Where HAEUI ${ }_{\mathrm{x}}$ and $\mathrm{CAEUI}_{\mathrm{x}}$ are the average space heating and cooling EUI for buildings constructed in age $\mathrm{x} ; \mathrm{HEUI}_{\mathrm{x}, \mathrm{y}}$ and $\mathrm{CEUI}_{\mathrm{x}, \mathrm{y}}$ are the space heating and cooling EUI of household category $\mathrm{y}$ constructed in age $\mathrm{x}$ where $\mathrm{x}$ is the construction age index which includes 3 classes, namely Pre-2001, 2002-2010 and Post-2011. The average space heating and cooling EUIs for residential buildings constructed in these classes are listed in Table 6. 
Table 6: Average space heating and cooling EUIs for different construction ages

Northern China pattern

HSCW pattern

Construction Space heating Space cooling Space heating Space cooling age natural gas EUI electricity EUI electricity EUI electricity EUI $\left(\mathrm{kWh} / \mathrm{m}^{2}\right) \quad\left(\mathrm{kWh} / \mathrm{m}^{2}\right) \quad\left(\mathrm{kWh} / \mathrm{m}^{2}\right) \quad\left(\mathrm{kWh} / \mathrm{m}^{2}\right)$

\begin{tabular}{lllll}
\hline Pre-2001 & 95.2 & 20.3 & 12 & 20.3 \\
$2002-2010$ & 48.5 & 15 & 7.4 & 15 \\
Post-2011 & 47.5 & 13.2 & 7.5 & 13.2 \\
\hline
\end{tabular}

As different types of energy were consumed for space heating, to compare the energy and carbon performance of the northern China pattern and the HSCW pattern in space heating, their primary energy consumption as well as carbon dioxide emissions were calculated using the following equations 7-8

$\mathrm{S}=\mathrm{EUI} \times \mathrm{I}_{\mathrm{p}}$

Where,

$\mathrm{S}$ is the source energy use intensity;

EUI is the studied energy use intensity;

$I_{p}$ is the site to source energy conversion factor.

$\mathrm{C}=\mathrm{EUI} \times \mathrm{I}_{\mathrm{c}}$

Where,

$\mathrm{C}$ is the carbon dioxide emission intensity;

$\mathrm{I}_{\mathrm{c}}$ is the $\mathrm{CO}_{2}$ emission factor.

The $I_{p}$ values are 3.167 for electricity and 1.084 for natural gas(Zhao et al., 2015). The $\mathrm{I}_{\mathrm{c}}$ values are $0.5257 \mathrm{kgCO}_{2} / \mathrm{kWh}$ for electricity (NCSC, 2014) and $56,100 \mathrm{kgCO}_{2} / \mathrm{TJ}$ for natural gas(IPCC, 2006). As the cooling energy usage is the same under the two different patterns, only source energy use intensity and carbon dioxide emission intensity for space heating are shown in Figure 8 and Figure 9 to compare the performance. 


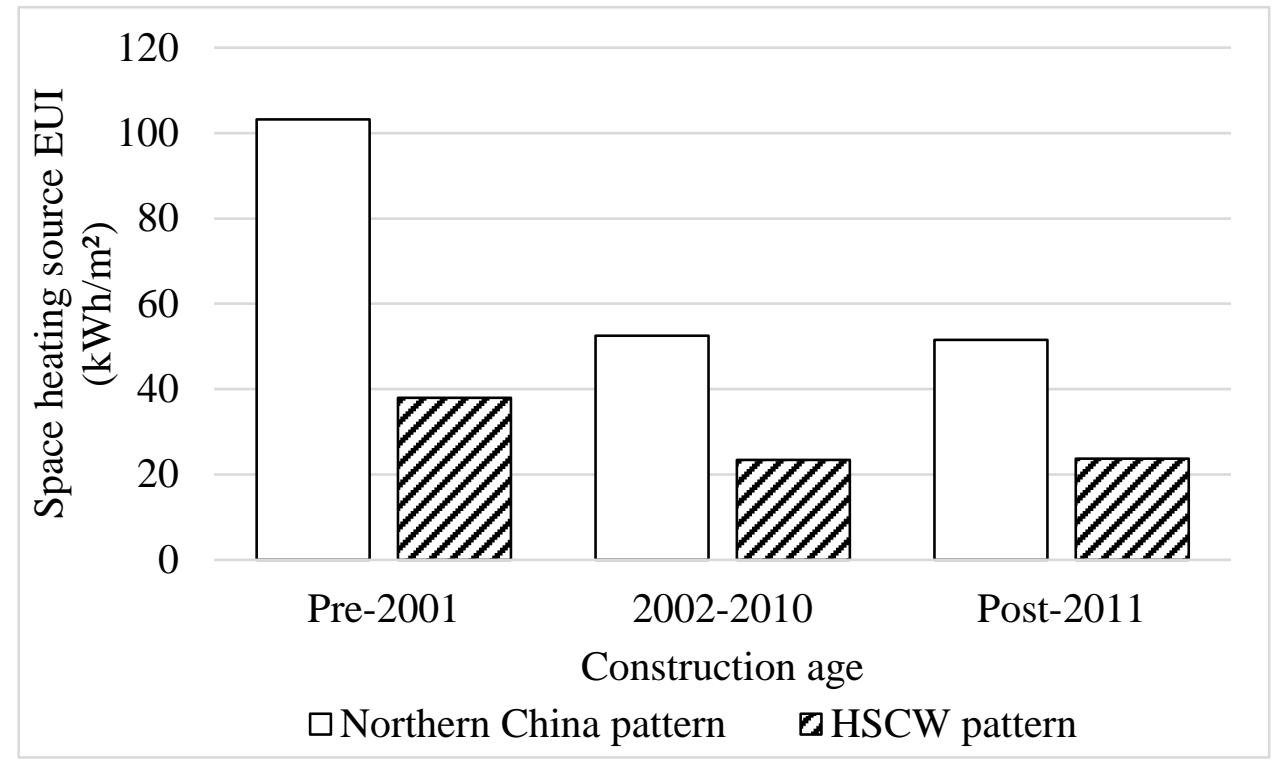

Figure 8: The space heating source EUI under different heating patterns

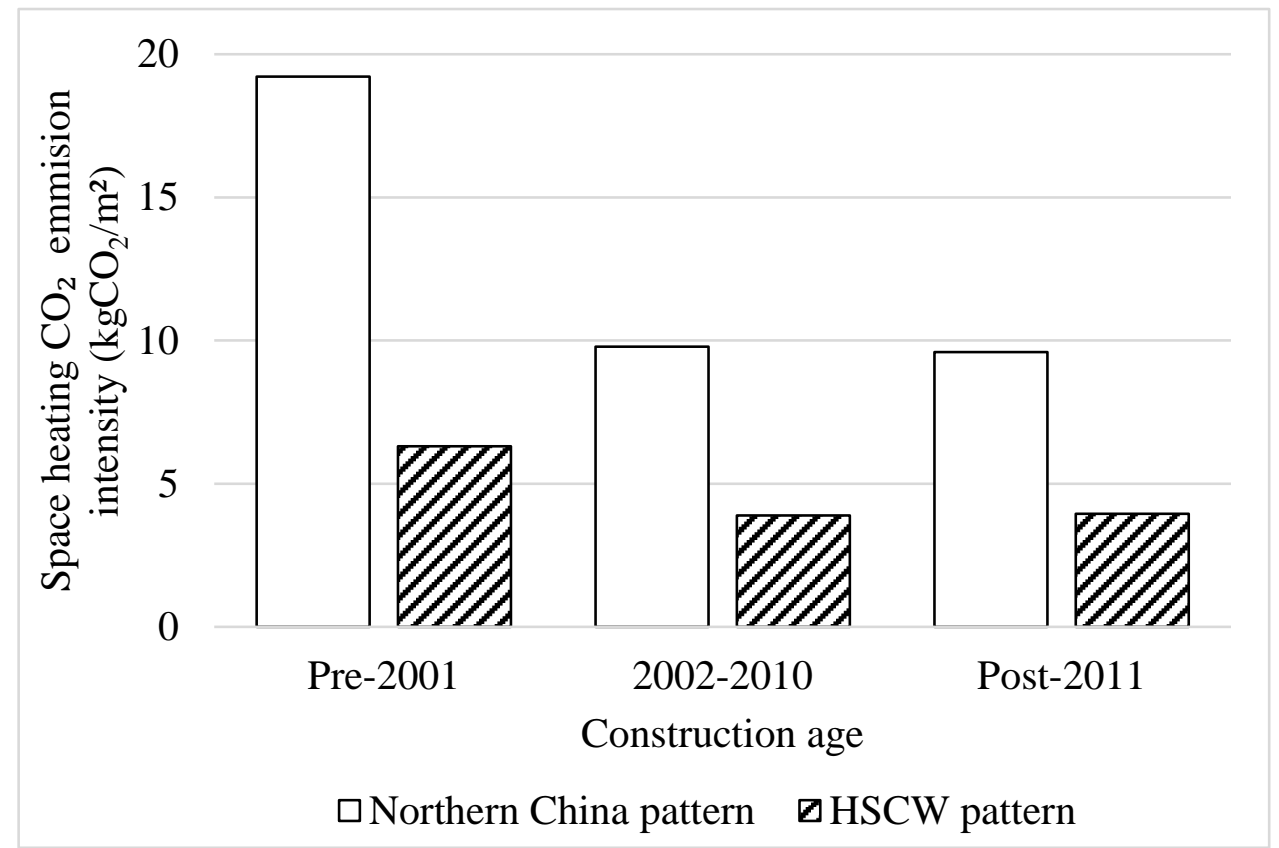

Figure 9: The space-heating-related carbon dioxide emission intensity under different heating patterns

It is clear that applying northern China type District Heating in Chongqing urban residential stock will dramatically increase both source energy consumption and carbon emissions no matter what the construction age group of the building is. The evidence suggests that northern China pattern space heating is not suitable for application within the hot summer and cold winter zone considering the national goal of energy conservation and carbon emission reduction. Therefore, the current HSCW pattern should be encouraged to continue in the future to achieve the balance between a comfortable indoor thermal environment and the low carbon and energy conservation 
targets.

\section{Stock total floor area calculation and construction age distribution}

As a sub-provincial city of Sichuan Province, Chongqing became a municipality on 14 March 1997 and is currently the youngest municipality with the largest land take. Chongqing's urban residential building stock is studied in this section to yield the existing urban residential floor area, future floor area projections, and the construction age distribution by relative floor area.

\subsection{The existing urban residential floor area}

The residential building average EUIs corresponding to different construction ages have been calculated in section 4.3 but the urban residential floor area in Chongqing is needed for calculating stock space heating and cooling energy needs. Based on the official Chongqing statistical yearbook (Chongqing Minicipal Bureau of Statistics \& NBS Survey Office in Chongqing, 2001-2016), the existing urban residential floor area in Chongqing is calculated using the following equation 9 ,

$\mathrm{URFA}_{\mathrm{t}}=\mathrm{RFP}_{\mathrm{t}} \times \mathrm{UP}_{\mathrm{t}}$

Where, URFA $t$ is the total urban residential floor area in Chongqing in year t;

$\mathrm{RFP}_{\mathrm{t}}$ is the urban residential floor area per person in year $\mathrm{t}$; and

$\mathrm{UP}_{\mathrm{t}}$ is the urban population in Chongqing in year $\mathrm{t}$.

The existing urban residential floor area, has increased continuously from 2000 to 2015, as shown in Figure 10. In 2015, the existing urban residential floor area was nearly 6 times the residential floor area of just 15 years earlier in 2000 . 




Figure 10: Urban residential floor area in Chongqing from 2000 to 2015

The urban residential floor area in Chongqing for 2010 is calculated as 484.7 million $\mathrm{m}^{2}$. This data, together with the 2010 census data (NBS, 2010) giving the floor area construction age distribution, gives the urban residential floor area construction age distribution in 2010 as presented in Table 7.

Table 7: 2010 construction age distribution for Chongqing urban residential floor area

Construction age Percentage

\begin{tabular}{rrr}
\hline pre-1949 & $0.99 \%$ & 478.0 \\
$1950-1959$ & $0.63 \%$ & 307.0 \\
$1960-1969$ & $1.43 \%$ & 691.9 \\
$1970-1979$ & $3.61 \%$ & 1751.9 \\
$1980-1989$ & $12.45 \%$ & 6035.9 \\
$1990-1999$ & $31.95 \%$ & 15486.2 \\
$2000-2010$ & $48.94 \%$ & 23720.6 \\
\hline
\end{tabular}

Urban residential floor area (unit: $10,000 \mathrm{~m}^{2}$ ) 
5.2 The projection of the future urban residential floor area

The projection of the future urban residential floor area also utilized equation 9, but uses the future urban population and the future residential floor area per person. The total Chongqing urban population was $18,384,100$ in 2015. The future Chongqing urban population trend was assumed to follow the United Nations projection for China (UN, 2014), with the projected average annual rate of change of the urban population presented in Table 8.

Table 8: Average annual rate of change of the urban population(UN, 2014)

\begin{tabular}{ll}
\hline Period & Average annual rate of change of the urban population \\
\hline $2015-2020$ & $2.30 \%$ \\
$2020-2025$ & $1.61 \%$ \\
$2025-2030$ & $1.06 \%$ \\
$2030-2035$ & $0.61 \%$ \\
$2035-2040$ & $0.28 \%$ \\
$2040-2045$ & $0.12 \%$ \\
$2045-2050$ & $-0.02 \%$ \\
\hline
\end{tabular}

The post 2015 urban population for Chongqing can be calculated using the following equation 10 ,

$\mathrm{UP}_{\mathrm{t}+1}=\mathrm{UP}_{\mathrm{t}} \times(1+\mathrm{r})$

Where $\mathrm{UP}_{\mathrm{t}+1}$ is the urban population in Chongqing in year $\mathrm{t}+1$;

$r$ is the average annual rate of change for the urban population (presented in Table 8). The urban population in Chongqing at year 2020 and 2050 are 20.6 million and 24.7 million respectively.

The future residential floor area per person in Chongqing urban residential stock was assumed to have four scenarios as follows:

1) S1: The future residential floor area per person stays at the same level for future years and remains at $35 \mathrm{~m}^{2}$ per person.

2) S2: The future residential floor area per person reaches $40 \mathrm{~m}^{2}$, which is the average residential floor area per person value for economic great powers including France, Germany, the United Kingdom, and Japan (THUBERC, 2017).

3) S3: The future residential floor area per person reaches $55 \mathrm{~m}^{2}$, which is the average residential floor area per person value for Denmark, Norway and Canada 
(THUBERC, 2017).

4) S4: The future residential floor area per person reaches $60 \mathrm{~m}^{2}$, which is assumed to be the upper boundary of residential floor area per person, considering the high population density and the shortage of habitable land resources in China (Hong et al., 2016a).

The future urban residential floor area in Chongqing under different scenarios is calculated and presented in Figure 11 together with the future urban population projections.

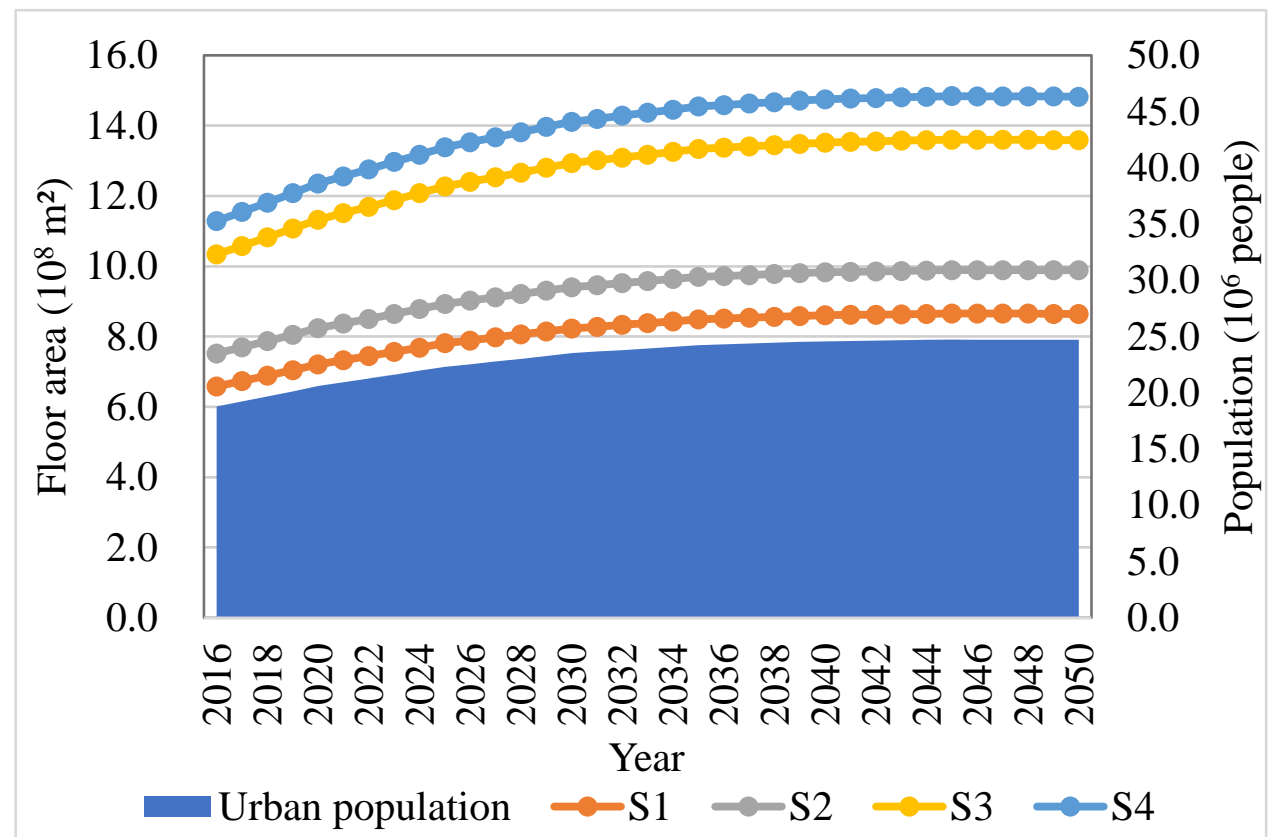

Figure 11: The future urban residential floor area and population projections for Chongqing

\subsection{The construction age distribution}

The past and future urban residential floor areas are known after the statistical-databased calculation in section 5.1 and future projections in section 5.2. The demolition of some existing buildings should be considered as it offsets some newly constructed floor area to give the total stock floor area increase. It also influences the building construction age distribution. Huang and Wu (2016) studied housing demolition in urban China and projected the 2011-2020 urban housing demolition rate (shown in Table 9). The urban housing demolition rate for Chongqing is assumed to equal that of China. The decadal urban housing demolition rate after 2020 (including 2021-2030, 2031-2040 and 2041-2050) is assumed to equal the 2011-2020 rate under the assumption that the demolition trend will be unchanged from 2011 to 2050 . The demolished floor area is calculated using the following equation 11, 
$\mathrm{DFA}=\mathrm{d} \times \mathrm{RFA}$

Where,

DFA is the demolished floor area; $d$ is the demolition rate (Table 9),

RFA is the remaining floor area at the end of the last decade.

Table 9: Decadal urban residential building demolition rate (Huang and $\mathrm{Wu}, 2016$ )

\begin{tabular}{ll}
\hline Construction age & Demolition rate \\
\hline pre-1949 & $34.78 \%$ \\
$1950-1959$ & $34.78 \%$ \\
$1960-1969$ & $30.60 \%$ \\
$1970-1979$ & $22.75 \%$ \\
$1980-1989$ & $18.39 \%$ \\
$1990-1999$ & $20.66 \%$ \\
$2000-2010$ & $3.16 \%$ \\
\hline
\end{tabular}

Following the building energy efficiency standards update, the construction age defined in section 3.3 split the 2000-2010 constructed residential building into two groups: pre2001 and 2002-2010. The existing 2000-2010 floor area is assumed to be evenly distributed over the 11 years for simplification. The post-2011 floor area increase amount is estimated as the sum of demolished floor area and floor area net growth between the studied and previous decade. Post-2011 floor area is assumed to always remain without demolition, as they will be less than 40 years old even in 2050 and the design lifespan for general buildings is 50 years (MOHURD, 2005), with the average real life for urban buildings as 30-40 years(Yang and Kohler, 2007; Yu et al., 2014a). The construction age distribution for the four future projection scenarios is presented in Figure 12.


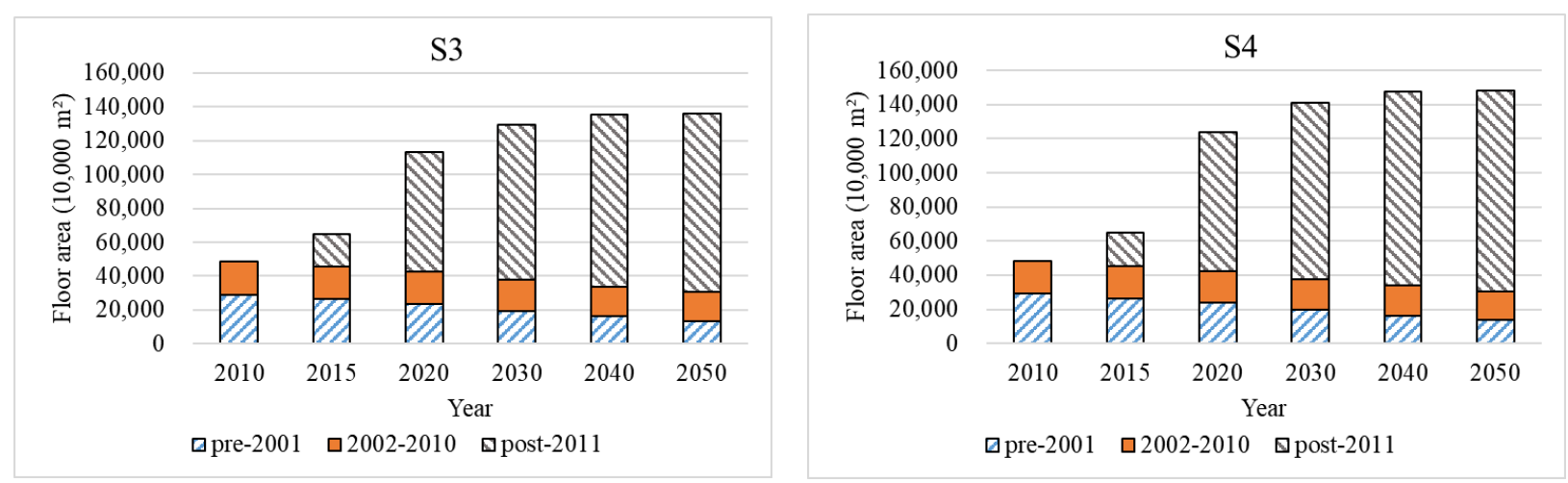

Figure 12: Chongqing urban residential floor area construction age distribution under four different scenarios

\section{Weather adjustments}

As the performance comparison in Section 4 had already reach the conclusion that current HSCW pattern space heating should be encouraged to continue in future, the following space heating and cooling energy consumption analysis has been made based on the assumption that space heating and cooling usage patterns will stay unchanged as the HSCW pattern.

\subsection{Stock average space heating and cooling EUIs}

The average space heating and cooling EUIs for the whole residential stock covering different construction ages was calculated using the following equations, 12-14,

$$
\begin{aligned}
& \text { HSEUI }=\sum H A E U I_{x} \times C A P_{x} \\
& \text { CSEUI }=\sum C A E U I_{x} \times C A P_{x} \\
& C A P_{x}=F A_{x} / U R F A
\end{aligned}
$$

Where, HSEUI and CSEUI are the stock average space heating and cooling EUIs under typical weather data;

CAPx is the percentage of floor area constructed in age $\mathrm{x}$;

FAx is the floor area constructed in age $\mathrm{x}$;

URFA is the total urban residential floor area. 
The average space heating and cooling EUIs and related carbon dioxide emissions for the Chongqing urban residential stock at different time points have been calculated and presented in Table 10. The heating EUI for the year 2015 generated from this model is $9.31 \mathrm{kWh} / \mathrm{m}^{2}$, which is close to the study by Wang et al. (2015) at $9.8 \mathrm{kWh} / \mathrm{m}^{2}$ with variation of only $-5 \%$. The cooling EUI for the year 2015 generated from this model is $16.63 \mathrm{kWh} / \mathrm{m}^{2}$, which is within the cooling EUI range (between $9.3 \mathrm{kWh} / \mathrm{m}^{2}$ and 21.6 $\mathrm{kWh} / \mathrm{m}^{2}$ ) from the study by Liu et al. (2014). Referring to the existing studies, it is further convinced the degree of the satisfaction of accuracy of the developed model.

Table 10: Stock average space heating and cooling EUIs and related carbon dioxide emissions with the stock construction age variation only

\begin{tabular}{rlrrrrrrrr}
\hline \multirow{2}{*}{ Scenarios } & \multicolumn{3}{c}{ Electricity $\mathbf{E U I}\left(\mathbf{k W h} / \mathbf{m}^{2}\right)$} & \multicolumn{3}{c}{$\mathrm{CO}_{2}$} & emissions & $\left(\mathrm{kgCO}_{2} / \mathbf{m}^{2}\right)$ \\
& 2010 & 2015 & 2020 & 2050 & 2010 & 2015 & 2020 & 2050 \\
\hline \multirow{2}{*}{ S1 } & Heating & 10.16 & 9.31 & 8.96 & 8.18 & 5.34 & 4.89 & 4.71 & 4.30 \\
& Cooling & 18.18 & 16.63 & 16.01 & 14.67 & 9.56 & 8.74 & 8.41 & 7.71 \\
\hline \multirow{2}{*}{ S2 } & Heating & 10.16 & 9.31 & 8.77 & 8.10 & 5.34 & 4.89 & 4.61 & 4.26 \\
& Cooling & 18.18 & 16.63 & 15.66 & 14.48 & 9.56 & 8.74 & 8.23 & 7.61 \\
\hline \multirow{2}{*}{ S3 } & Heating & 10.16 & 9.31 & 8.43 & 7.94 & 5.34 & 4.89 & 4.43 & 4.17 \\
& Cooling & 18.18 & 16.63 & 14.99 & 14.13 & 9.56 & 8.74 & 7.88 & 7.43 \\
\hline \multirow{2}{*}{ S4 } & Heating & 10.16 & 9.31 & 8.35 & 7.90 & 5.34 & 4.89 & 4.39 & 4.15 \\
& Cooling & 18.18 & 16.63 & 14.84 & 14.06 & 9.56 & 8.74 & 7.80 & 7.39 \\
\hline
\end{tabular}

\subsection{Past and future weather conditions}

The outdoor climate variation has a very significant impact on space heating and cooling energy consumption. Two indices, namely Heating Degree-Day (HDD) and Cooling Degree-Day (CDD), are commonly used to measure the sum of the daily variation of the temperature below or above a certain threshold and to adjust the heating and cooling energy demand (Isaac and van Vuuren, 2009). Although the degree-days based weather normalization has been criticized for its inherent limitations(Wang et al., 2016), this approach has been adapted in this study for its simplicity of use and the minimal amount of data required. The base temperatures chosen for HDD and CDD are $18^{\circ} \mathrm{C}$ and $26^{\circ} \mathrm{C}$ respectively(MOHURD, 2001). The degree-days were calculated according to equations $15-16$,

$$
\begin{aligned}
& \mathrm{HDD}_{18}=\sum_{i=1}^{365} h d d, \text { if } T_{\text {out }} \geq 18, \text { hdd }=0 ; \text { if } T_{\text {out }}<18, \text { hdd }=18-T_{\text {out }} \\
& \mathrm{CDD}_{26}=\sum_{i=1}^{365} c d d, \text { if } T_{\text {out }}>26, \text { cdd }=T_{\text {out }}-26 ; \text { if } T_{\text {out }} \leq 26, \text { cdd }=0
\end{aligned}
$$

Where $\mathrm{HDD}_{18}$ and $\mathrm{CDD}_{26}$ are the annually heating and cooling degree-days and $\mathrm{T}_{\text {out }}$ is the outdoor daily average temperature. 
As stated above in section 4.2, the weather data used in the EnergyPlus building energy simulation is the CSWD weather, which is the typical year weather data. The historic real weather conditions in 2010 and 2015 were collected from the China Meteorological Data Service Center(CMDC, 2017). Meanwhile, the climate change world weather file generator CCWorldWeatherGen (SERG, 2017) is used to generate the climate change future weather file under the IPCC HadCM3 A2 experiment ensemble. The A2 emissions scenario represents a 'business as usual' case for the global development of human emissions and can be considered as a 'likely'future development path over the timescale relevant to building design(Jentsch et al., 2013). Future weather data for Chongqing in 2020 and 2050 has been generated, the $\mathrm{HDD}_{18}$ and $\mathrm{CDD}_{26}$ for 2010, 2015, 2020 and 2050 as well as in the CSWD typical year is presented in Table 11.

Table 11: $\mathrm{HDD}_{18}$ and $\mathrm{CDD}_{26}$ for different weather conditions

\begin{tabular}{lll}
\hline Item & $\boldsymbol{H D D}_{\boldsymbol{1 8}}$ & $\boldsymbol{C D D}_{\mathbf{2 6}}$ \\
\hline CSWD typical year & 1102.7 & 182.8 \\
2010 & 1066.8 & 277.5 \\
2015 & 839.9 & 218.3 \\
2020 & 952.0 & 277.0 \\
2050 & 725.8 & 431.8 \\
\hline
\end{tabular}

Comparing to the CSWD typical year weather file, the 2010, 2015, 2020, and 2050 data have smaller HDD values and bigger CDD values. This indicates that the CSWD typical year weather file tends to overestimate heating energy consumption and underestimate cooling energy consumption with regard to the weather data of the specific year. It is also noted that, in 2050, the cooling degree-days will reach 431.8 , which is 2.36 times the value for the CSWD typical year.

\subsection{The weather adjusted stock average space heating and cooling EUIs}

The space heating and cooling EUIs for Chongqing urban residential building stock considering the weather adjustment are calculated using equations 17-19,

WHEUI $=\operatorname{HSEUI} \times{ }^{H D D_{18, s}} / H D D_{18, t}$

WCEUI $=$ CSEUI $\times{ }^{C D D_{26, s}} / C D D_{26, t}$

WTEUI $=$ WHEUI + WCEUI

Where, WHEUI, WCEUI and WTEUI are the weather adjusted stock average heating, cooling and total EUIs respectively; 
$\mathrm{HDD}_{18, \mathrm{~s}}$ and $\mathrm{CDD}_{26, \mathrm{~s}}$ are the heating and cooling degree-days for the studied year;

$\mathrm{HDD}_{18, \mathrm{t}}$ and $\mathrm{CDD}_{26, \mathrm{t}}$ are the heating and cooling degree-days for the CSWD typical year.

The weather adjusted stock average EUIs and related carbon dioxide emissions are shown in Table 12.

Table 12: Weather adjusted stock average space heating and cooling EUIs

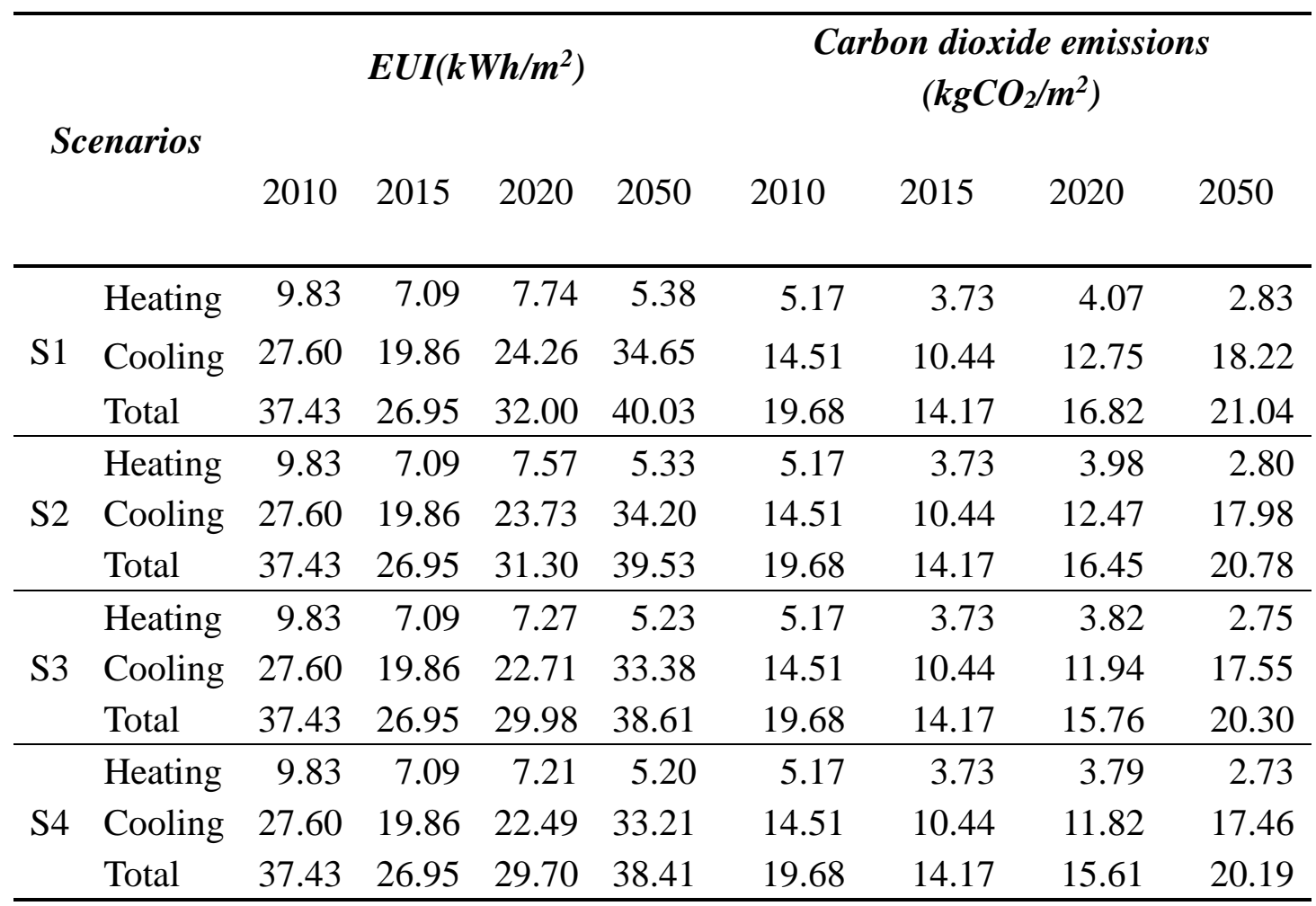

7 Evaluating the retrofit measures

As the current Chongqing urban residential building stock failed to perform well enough to achieve the $20 \mathrm{kWh} / \mathrm{m}^{2}$ space heating and cooling EUI goal (MOST, 2016; Wang, 2017), retrofit measures should be considered to improve its energy efficiency. The Chongqing green building technology recommendation list(CQGBC, 2017) 
introduced by the Chongqing Green Building Council was referenced for retrofit measures selection. As the technologies included in this list had already considered the building sector characteristics in Chongqing as well as the implications of the current situation and future technology development trends, their feasibility and usability for retrofitting the existing stock were already proved under the condition of little change being made to the building framework. As the space heating and cooling equipment in residential buildings are normally heat pump air conditioner units, retrofit measures using system optimization are not applicable, so the retrofit measures considered are as follows:

1) Improve the thermal physical performance of the building envelope;

2) Improve HVAC equipment efficiency.

The four energy conservation retrofit scenarios considered are presented in Table 13. The stock average weather adjusted space heating and cooling EUIs as well as the corresponding carbon dioxide emissions for the different scenarios are presented in Table 14.

Table 13: Retrofit scenarios

\begin{tabular}{ll}
\hline Retrofit scenarios & Scenario description \\
\hline RE-1 & All building envelope physical characteristics meet the current \\
& HSCW 2010 standard(MOHURD, 2010), while the HVAC \\
& equipment efficiency stays unchanged. \\
& All building envelope physical characteristics stay unchanged, \\
RE-2 & while the HVAC equipment efficiency is improved to an annual \\
& performance factor =3.5 (Energy efficiency rating level \\
& 3)(MOHURD, 2013a). \\
& All building envelope physical characteristics meet the current \\
& HSCW 2010 standard(MOHURD, 2010), while the HVAC \\
& equipment efficiency is improved to an annual performance \\
& factor =3.5 (Energy efficiency rating level 3) (MOHURD, \\
& 2013a). \\
& All building envelope physical characteristics meet the current \\
& HSCW 2010 standard(MOHURD, 2010), while the HVAC \\
& equipment efficiency is improved to an annual performance \\
factor $=4.0$ (Energy efficiency rating level 2) (MOHURD, & \\
& 2013a).
\end{tabular}


1 Table 14: Stock average space heating and cooling EUIs and its corresponding carbon dioxide emission intensities at different retrofit

2 scenarios

\begin{tabular}{|c|c|c|c|c|c|c|c|c|c|c|c|c|c|c|c|c|c|}
\hline \multirow{3}{*}{\multicolumn{2}{|c|}{ Scenarios }} & \multicolumn{8}{|c|}{$E U I\left(k W h / m^{2}\right)$} & \multicolumn{8}{|c|}{ Carbon dioxide emissions intensity $\left(\mathrm{kgCO}_{2} / \mathrm{m}^{2}\right)$} \\
\hline & & \multicolumn{2}{|c|}{$R E-1$} & \multicolumn{2}{|c|}{$R E-2$} & \multicolumn{2}{|c|}{$R E-3$} & \multicolumn{2}{|c|}{$R E-4$} & \multicolumn{2}{|c|}{$R E-1$} & \multicolumn{2}{|c|}{$R E-2$} & \multicolumn{2}{|c|}{$R E-3$} & \multicolumn{2}{|c|}{$R E-4$} \\
\hline & & 2020 & 2050 & 2020 & 2050 & 2020 & 2050 & 2020 & 2050 & 2020 & 2050 & 2020 & 2050 & 2020 & 2050 & 2020 & 2050 \\
\hline \multirow{3}{*}{$\mathrm{S} 1$} & Heating & 6.48 & 4.94 & 4.20 & 2.92 & 3.52 & 2.68 & 3.08 & 2.34 & 3.41 & 2.60 & 2.21 & 1.54 & 1.85 & 1.41 & 1.62 & 1.23 \\
\hline & Cooling & 20.00 & 31.18 & 15.94 & 22.77 & 13.14 & 20.49 & 9.50 & 14.81 & 10.51 & 16.39 & 8.38 & 11.97 & 6.91 & 10.77 & 4.99 & 7.79 \\
\hline & Total & 26.48 & 36.12 & 20.14 & 25.69 & 16.66 & 23.17 & 12.58 & 17.16 & 13.92 & 18.99 & 10.59 & 13.51 & 8.76 & 12.18 & 6.61 & 9.02 \\
\hline $\mathrm{S} 2$ & Heating & 6.48 & 4.94 & 4.11 & 2.89 & 3.52 & 2.68 & 3.08 & 2.34 & 3.41 & 2.60 & 2.16 & 1.52 & 1.85 & 1.41 & 1.62 & 1.23 \\
\hline \multirow{3}{*}{ S3 } & Heating & 6.48 & 4.94 & 3.95 & 2.84 & 3.52 & 2.68 & 3.08 & 2.34 & 3.41 & 2.60 & 2.08 & 1.49 & 1.85 & 1.41 & 1.62 & 1.23 \\
\hline & Cooling & 20.00 & 31.18 & 14.93 & 21.93 & 13.14 & 20.49 & 9.50 & 14.81 & 10.51 & 16.39 & 7.85 & 11.53 & 6.91 & 10.77 & 4.99 & 7.79 \\
\hline & Total & 26.48 & 36.12 & 18.88 & 24.77 & 16.66 & 23.17 & 12.58 & 17.16 & 13.92 & 18.99 & 9.93 & 13.02 & 8.76 & 12.18 & 6.61 & 9.02 \\
\hline \multirow[b]{2}{*}{$\mathrm{S} 4$} & Heating & 6.48 & 4.94 & 3.91 & 2.82 & 3.52 & 2.68 & 3.08 & 2.34 & 3.41 & 2.60 & 2.06 & 1.48 & 1.85 & 1.41 & 1.62 & 1.23 \\
\hline & Cooling & 20.00 & 31.18 & 14.78 & 21.82 & 13.14 & 20.49 & 9.50 & 14.81 & 10.51 & 16.39 & 7.77 & 11.47 & 6.91 & 10.77 & 4.99 & 7.79 \\
\hline
\end{tabular}


4 All four energy conservation retrofit scenarios are beneficial to the reduction of stock

5 average space heating and cooling EUIs and the carbon dioxide emission intensities,

6 while RE-4 can achieve the highest energy conservation and carbon reduction. By

7 applying RE-4 under even the most severe future weather conditions in 2050, the total

8 space heating and cooling EUIs below $20 \mathrm{kWh} / \mathrm{m}^{2}$ can be achieved with carbon dioxide

9 emissions of less than $10 \mathrm{kgCO}_{2} / \mathrm{m}^{2}$.

10 A comparative cost analysis is included to assist the evaluation of energy conservation 11 retrofit measures, The net present value of delivered electricity savings had been

12 calculated using equations 20-21 (Stephan and Stephan, 2016; Wang et al., 2014),

$13 \quad \mathrm{PV}=\sum_{i=1}^{n} \frac{C_{i}}{(1+r)^{i}}$

$C_{i}=\mathrm{p}_{e} \times(1+C P I)^{i} \times\left(\mathrm{WHEUI}_{b a u, i}+\mathrm{WCEUI}_{b a u, i}-\mathrm{WHEUI}_{r, i}-\mathrm{WCEUI}_{r, i}\right)$

15 Where,

$16 \mathrm{PV}$ is the accumulated present value of delivered electricity savings per floor $17 \operatorname{area}\left(\mathrm{RMB} / \mathrm{m}^{2}\right)$;

$18 \mathrm{n}$ is the assumed payback periods (year);

$19 \mathrm{r}$ is the annual discount rate(3.9\%), which is assumed to be equal to the annual interst 20 rate of Chinese national debt(MOF, 2018);

$21 C_{i}$ is the delivered electricity saving at the $\mathrm{i}^{\text {th }}$ year per floor area $\left(\mathrm{RMB} / \mathrm{m}^{2}\right)$; $\mathrm{p}_{e}$ is the electricity price at base year $(\mathrm{RMB} / \mathrm{kWh})$, which is set as $0.57 \mathrm{RMB} / \mathrm{kWh}$ (THUBERC, 2017), the same as the second level electricity price in

24 Chongqing;

CPI is the considered inflation rate(1.93\%), which is computed as the average of the consumer price index (CPI) over the last 20 years(NBS, 2018);

WHEUI $_{b a u, i}$ and WCEUI $\mathrm{Wau}, i$ are the weather adjusted stock average heating and cooling EUIs for business-as-usual scenarios, where no action has been taken to improve residential building energy efficiency, at $\mathrm{i}^{\text {th }}$ year $\left(\mathrm{kWh} / \mathrm{m}^{2}\right)$;

30 WHEUI $_{r, i}$ and WCEUI $_{r, i}$ are the weather adjusted stock average heating and cooling 31 EUIs for retrofitted scenarios at $\mathrm{i}^{\text {th }}$ year $\left(\mathrm{kWh} / \mathrm{m}^{2}\right)$. 


\begin{tabular}{|c|l|r|r|r|r|}
\hline Payback period & Scenarios & \multicolumn{1}{|c|}{ S1 } & \multicolumn{1}{c|}{ S2 } & \multicolumn{1}{c|}{ S3 } & \multicolumn{1}{c|}{$S 4$} \\
\hline \multirow{4}{*}{ 15 Years } & RE-1 & 33.24 & 29.02 & 21.08 & 19.40 \\
\cline { 2 - 6 } & RE-2 & 76.35 & 74.79 & 71.81 & 71.26 \\
\cline { 2 - 6 } & RE-3 & 97.35 & 93.13 & 85.20 & 83.51 \\
\cline { 2 - 6 } & RE-4 & 124.52 & 120.30 & 112.36 & 110.68 \\
\hline \multirow{5}{*}{ 25 Years } & RE-1 & 51.35 & 44.82 & 32.59 & 29.98 \\
\cline { 2 - 6 } & RE-2 & 126.97 & 124.56 & 120.01 & 119.15 \\
\cline { 2 - 6 } & RE-3 & 159.49 & 152.97 & 140.73 & 138.12 \\
\cline { 2 - 6 } & RE-4 & 206.22 & 199.70 & 187.46 & 184.85 \\
\hline \multirow{5}{*}{35 Years } & RE-1 & 64.59 & 56.38 & 41.01 & 37.73 \\
\cline { 2 - 6 } & RE-2 & 171.40 & 168.38 & 162.72 & 161.63 \\
\cline { 2 - 6 } & RE-3 & 212.42 & 204.21 & 188.85 & 185.56 \\
\cline { 2 - 6 } & RE-4 & 277.36 & 269.14 & 253.78 & 250.49 \\
\hline
\end{tabular}

\section{Stock space heating and cooling energy consumption}

51 The weather adjusted stock total space heating and cooling energy consumption of

52 residential buildings in the Chongqing urban area can be calculated using the following 53 equations 22-23.

$54 \quad$ WHEUI $=$ WHEUI $\times U R F A$ 
The weather adjusted stock space heating and cooling energy consumption for 2010, 2015, 2020 and 2050 under different scenarios are presented in Figure 13. The Chongqing urban residential stock space heating and cooling total energy consumptions are $18.1 \times 10^{9}$ and $17.4 \times 10^{9} \mathrm{kWh}$ respectively for 2010 and 2015 respectively. For the business-as-usual (BAU) scenarios, where no action has been taken to improve residential building energy efficiency, the space heating and cooling total energy consumption can reach $23.1-36.7 \times 10^{9} \mathrm{kWh}$ for 2020 and $34.6-56.9 \times 10^{9} \mathrm{kWh}$ for 2050. All four energy conservation retrofit scenarios show reductions in residential stock space heating and cooling energy consumption. Under S1 and S2 future residential building stock development scenarios and by applying the most prestige bundle of retrofit measures (RE-4), the future stock space heating and cooling energy consumption will be reduced from the current 2015 level. However, for scenarios S3 and S4, even applying retrofit measures bundle RE-4 cannot stop the energy consumption increasing in the future. This further stresses the importance of total residential floor area and per person floor area control as discussed by Peng and Jiang (2015). The carbon dioxide emissions for the corresponding scenarios are shown in Figure 14. The space heating and cooling related carbon dioxide emissions for Chongqing urban residential stock are $9.5 \times 10^{9} \mathrm{kgCO}_{2}$ and $9.2 \times 10^{9} \quad \mathrm{kgCO}_{2}$ respectively for 2010 and 2015 . The stock space heating and cooling related carbon dioxide emissions are 12.1-19.3 $\times 10^{9} \mathrm{kgCO}_{2}$ and $18.2-29.9 \times 10^{9} \mathrm{kgCO}_{2}$ for 2020 and 2050 for the business-as-usual(BAU) scenarios. However, by applying the highest prestige bundle of retrofit measures (RE-4), the residential stock space heating and cooling related carbon dioxide emissions can be reduced to only $4.8-8.2 \times 10^{9} \mathrm{kgCO}_{2}$ for 2020 and $7.8-13.4 \times 10^{9} \mathrm{kgCO}_{2}$ for 2050 . 


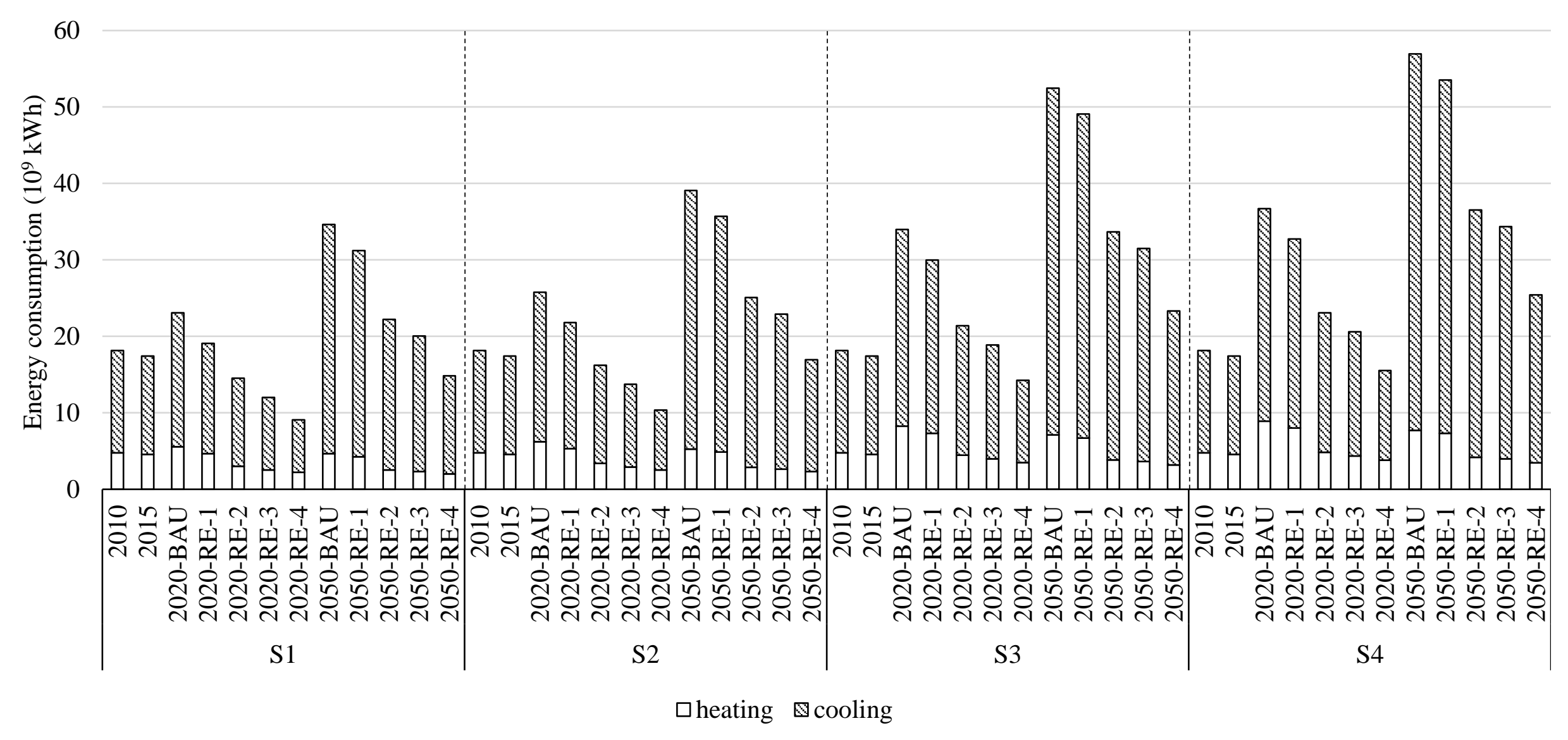

Figure 13: The Chongqing urban residential stock space heating and cooling energy consumption 


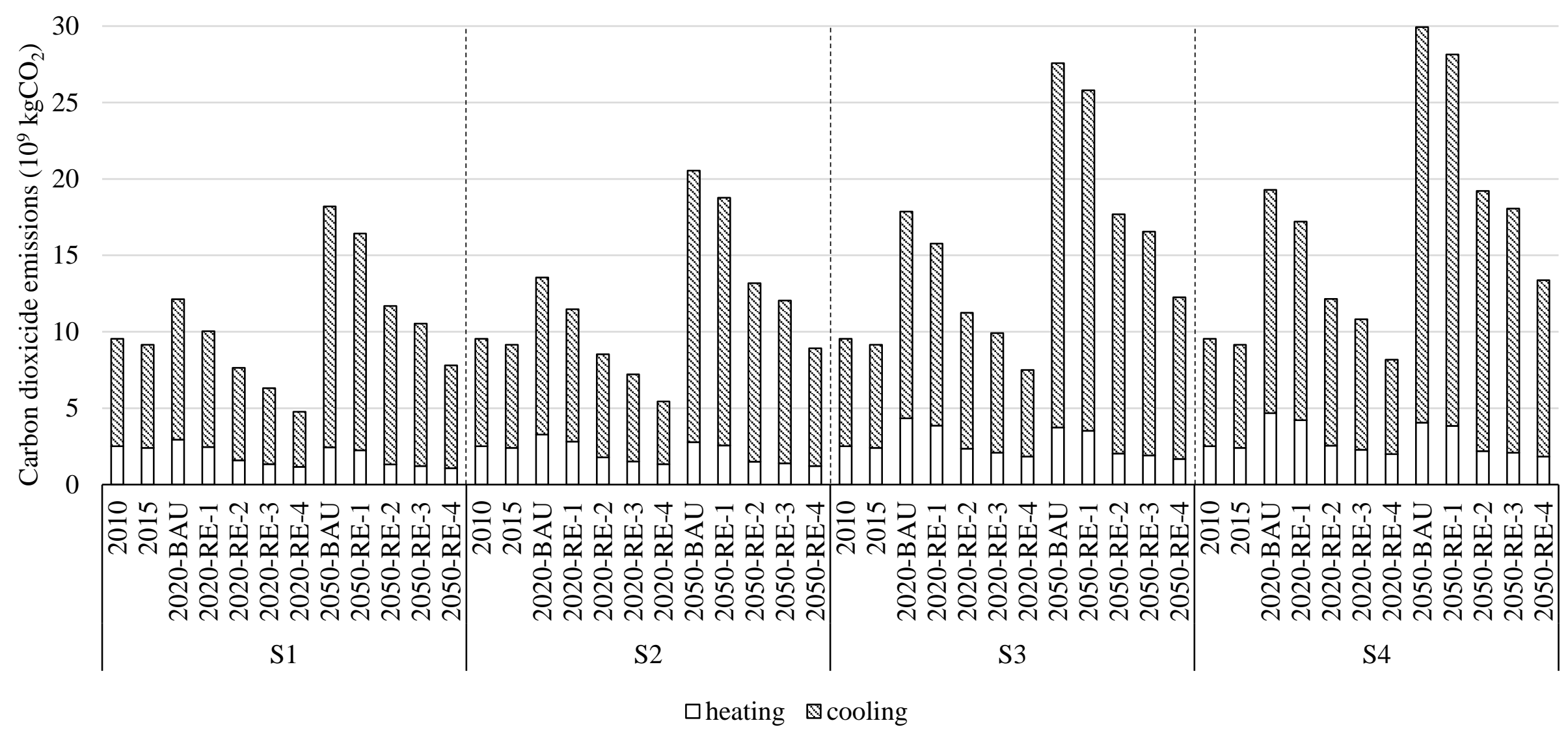

Figure 14: The Chongqing urban residential stock space heating and cooling related carbon dioxide emissions 
The space heating and cooling total energy saving/carbon dioxide emission reduction percenteges for different retrofit scenarios compared to the business-as-usual scenario are shown in Table 16. The application of RE-1 can achive more than $10 \%$ energy saving and carbon reduction in 2020, this figure is smaller in 2050 at less than $10 \%$. For the RE-4 scenario, the space heating and cooling total energy saving/carbon dioxide emissions reduction percentages vary from $57.6 \%$ to $60.7 \%$ in 2020 and $55.3 \%$ to $57.2 \%$ in 2050.

Table 16: The space heating and cooling total energy saving/carbon dioxide emission reduction percenteges for different retrofit scenarios

\begin{tabular}{ccccccccc}
\hline \multirow{2}{*}{ Scenarios } & \multicolumn{4}{c}{$\mathbf{2 0 2 0}$} & \multicolumn{5}{c}{$\mathbf{2 0 5 0}$} \\
& RE-1 & RE-2 & RE-3 & RE-4 & RE-1 & RE-2 & RE-3 & RE-4 \\
\hline S1 & $17.2 \%$ & $37.0 \%$ & $47.9 \%$ & $60.7 \%$ & $9.8 \%$ & $35.8 \%$ & $42.1 \%$ & $57.2 \%$ \\
S2 & $15.4 \%$ & $37.1 \%$ & $46.8 \%$ & $59.8 \%$ & $8.6 \%$ & $35.8 \%$ & $41.4 \%$ & $56.6 \%$ \\
S3 & $11.7 \%$ & $37.1 \%$ & $44.5 \%$ & $58.1 \%$ & $6.4 \%$ & $35.8 \%$ & $40.0 \%$ & $55.6 \%$ \\
S4 & $10.8 \%$ & $37.1 \%$ & $43.9 \%$ & $57.6 \%$ & $6.0 \%$ & $35.8 \%$ & $39.7 \%$ & $55.3 \%$ \\
\hline
\end{tabular}

\section{Discussion}

As mentioned above, due to the lack of statistical data about residential building space heating and cooling energy consumption as well as the lack of a representative residential building energy consumption survey, there are not much data available to calibrate the space heating and cooling energy consumption calculated from Chongqing urban residential stock model. Results from other research papers are referenced to attempt to check the accuracy. Further large scale residential stock surveys are needed to collect more information about the space heating and cooling energy consumption in the Chongqing urban area. Moreover, the authors argue that in residential buildings, energy consumption, as well as the end-use residential buildings energy consumption, including but not limited to the consumption of space heating and cooling energy, should be considered urgently as a part of energy consumption statistical data collection.

It is important to note that for all of the space heating and cooling energy consumption presented above, occupant behavior, including responses to heating and cooling setpoints and, the operation of heating and cooling, is assumed to remain unchanged from 2010 to 2050 under the sequence of changing scenarios. However, in reality occupant behavior might vary in building retrofit scenarios, exhibiting what is commonly known as the 'rebound effect', in which occupants' aspirations for a more comfortable and convenient lifestyle drive the installation of more energy services in a building even as building energy efficiency improves (Lin and Liu, 2015). Changing occupant behavior has led to energy saving uncertainty as occupant behaviors emerge 
as an important feature in building energy consumption (Delzendeh et al., 2017; Happle et al., 2018; Hong et al., 2016b; Paone and Bacher, 2018). So future research will consider the impact of occupant behavior on energy saving outcomes within the residential stock.

\section{Conclusions}

This paper presents a newly developed bottom-up engineering building energy modeling approach for residential space heating and cooling energy consumption and carbon emissions calculation. The key elements in developing the bottom-up engineering residential stock model include: 1) developing building archetypes; categorizing construction age, household composition, and floor plan; 2) archetypes energy simulation and aggregation; 3) estimating the stock floor area and floor area age distribution analysis; 4) weather adjustments.

Four energy conservation retrofit adaptation schemes are proposed with consideration of both a passive strategy for improving building envelope performance and an active strategy for improving HVAC equipment efficiency. The developed stock modeling approach can provide evidence and strategic guidance for policy-makers and building energy designers on the retrofitting and designs. The method is applicable to any other region so long as the information for the individual cities/regions is available. A case study of Chongqing city has been conducted to demonstrate the application of the proposed approach; the main findings are as follows:

- The northern China space-heating pattern using a centralised heating system continuously should not be considered in Chongqing, which is located in the Hot Summer and Cold Winter zone, as it will dramatically increase both primary energy consumption and carbon dioxide emissions from space heating usage.

- The urban residential floor area in Chongqing increased continuously from 2000 to 2015. Under four different future scenarios, the urban residential floor area in Chongqing is projected to become stable. The pre-2001 and 2002-2010 residential buildings will gradually undergo a demolition process, leading to an increasing percentage of post-2010 residential buildings.

- Energy conservation retrofit measures can significantly reduce total space heating and cooling EUIs and the intensity of carbon dioxide emissions to $12.58 \mathrm{kWh} / \mathrm{m}^{2}$ and $6.61 \mathrm{kgCO} / \mathrm{m}^{2}$ for 2020 and $17.16 \mathrm{kWh} / \mathrm{m}^{2}$ and 9.02 $\mathrm{kgCO}_{2} / \mathrm{m}^{2}$ for 2050 . The space heating and cooling total energy saving/carbon dioxide emission reduction percentage for Chongqing urban residential stock can reach $57.6 \%$ to $60.7 \%$ in 2020 and $55.3 \%$ to $57.2 \%$ in 2050 . 
- Apart from the energy conservation retrofit measures, controlling total residential floor area and per person floor area is important for lowering total stock space heating and cooling energy consumption and carbon dioxide emissions.

The developed bottom-up engineering stock model for residential buildings can be applied to any other cities with the required information following the step-by-step approach described in this paper. The energy stock modelling can provide insights into current and future energy consumption in residential buildings and assist local authorities in decision-making about the most appropriate building retrofitting strategies.

\section{Acknowledgement}

This research is financially supported by the National Key R\&D Programme 'Solutions to Heating and Cooling of Buildings in the Yangtze River Region' [Grant No: 2016YFC0700301] in association with the 'LoHCool project'- Low carbon climate responsive heating and cooling of cities funded by the Natural Science Foundation of China [Grant No: NSFC 51561135002] and the UK Engineering and Physical Sciences Research Council [Grant No: EPSRC EP/N009797/1].

\section{References}

Ahn, K.-U., Kim, D.-W., Park, C.-S., de Wilde, P., 2017. Predictability of occupant presence and performance gap in building energy simulation. Applied Energy 208, $1639-1652$.

An, J., Yan, D., Hong, T., Sun, K., 2017. A novel stochastic modeling method to simulate cooling loads in residential districts. Applied Energy 206, 134-149.

Baeumler, A., Ijjasz-Vasquez, E., Mehndiratta, S., 2012. Sustainable low-carbon city development in China. World Bank Publications.

Ballarini, I., Corgnati, S.P., Corrado, V., 2014. Use of reference buildings to assess the energy saving potentials of the residential building stock: The experience of TABULA project. Energy Policy 68, 273-284.

CABEE, 2016. China Building Energy Consumption Report. China Association of 
185 Caputo, P., Costa, G., Ferrari, S., 2013. A supporting method for defining energy 186 strategies in the building sector at urban scale. Energy Policy 55, 261-270.

190 Chen, Y., Liang, X., Hong, T., Luo, X., 2017. Simulation and visualization of energy191 related occupant behavior in office buildings. Building Simulation 10, 785-798.

192 Cheng, V., Steemers, K., 2011. Modelling domestic energy consumption at district scale: 193 A tool to support national and local energy policies. Environmental Modelling \& 194 Software 26, 1186-1198.

195 China Daily. Debate gets hot on issue of heating South China. 2013; 196 http://usa.chinadaily.com.cn/epaper/2013-01/08/content_16095460.htm (accessed $197 \quad 2015.5 .15)$

198 Chongqing Minicipal Bureau of Statistics \& NBS Survey Office in Chongqing, 2001199 2016. Chongqing Statistical Yearbook. China Statistic Press, Beijing.

200 Chongqing Minicipal Bureau of Statistics \& NBS Survey Office in Chongqing, 2016.

201 Chongqing Statistical Yearbook. China Statistic Press, Beijing.

202 Chongqing municipal commission of urban-rural development, 2016. Design standards 203 on residnetial building energy saving 65\% (green buildings) DBJ50-071-2016.

204 Chongqing Statistics Bureau, 2012. Tabulation on the 2010 population census of 205 Chongqing municipality. China Statistics Press.

206 Chongqing Statistics Bureau. Yearly data-urban construction. 2016; 207 http://www.cqdata.gov.cn/easyquery.htm?cn=A0103 (accessed 2017.12.25)

208 CMDC, 2017. China Ground International Exchange Station Climate Data Daily 209 Datasets (V3.0), in: Center, C.M.D.S. (Ed.), 3.0 ed.

210 CQGBC, 2017. Annual report on the development of green buildings in Chongqing 211 2016. Chongqing University Press, Chongqing.

212 CQMPG. The "thirteenth five-year plan" of energy saving and resources conservation 
214 http://www.cq.gov.cn/publicinfo/web/views/Show!detail.action?sid=4160076

$215 \quad$ (accessed 2018.5.15)

216 Dascalaki, E.G., Droutsa, K.G., Balaras, C.A., Kontoyiannidis, S., 2011. Building 217 typologies as a tool for assessing the energy performance of residential buildings - A 218 case study for the Hellenic building stock. Energy and Buildings 43, 3400-3409.

219 Delzendeh, E., Wu, S., Lee, A., Zhou, Y., 2017. The impact of occupants' behaviours 220 on building energy analysis: A research review. Renewable and Sustainable Energy 221 Reviews 80, 1061-1071.

222 Department for Business Energy \& Industrial Strategy, 2017. Energy consumption in 223 the UK 2017.

224 Department of Climate Change, 2015. Enhanced actions of climate change: China's 225 intended nationally determined contributions. National Development \& Reform 226 Commission of China.

DOE. EnergyPlus Energy Simulation Software.

2017;

228 http://apps1.eere.energy.gov/buildings/energyplus/ (accessed 2017.12.14)

229 DOE. Testing and Validation. 2018; https://energyplus.net/testing

230 EIA. Heating and cooling no longer majority of U.S. home energy use. 2013; $231 \mathrm{https}: / / \mathrm{www}$. eia.gov/todayinenergy/detail.php?id=10271\&src=\%E2\%80\%B9\%20Con 232 sumption $\% 20 \% 20 \% 20 \% 20 \% 20 \% 20$ Residential\%20Energy\%20Consumption\%20Sur 233 vey\%20(RECS)-f4 (accessed 2018.2.18)

234 EIA. Residential Energy Consumption Survey (RECS). 2017; 235 https://www.eia.gov/consumption/residential/ (accessed 2017.10.16)

236 EPA. Global Greenhouse Gas Emissions Data. 2017; 237 https://www.epa.gov/ghgemissions/global-greenhouse-gas-emissions-data (accessed $238 \quad 2018.5 .14)$

239 Eurostat. Energy consumption in households. 2018;

240 http://ec.europa.eu/eurostat/statistics-

241 explained/index.php/Energy_consumption_in_households\#cite_note-1 (accessed $242 \quad 2018.3 .2)$

243 Filogamo, L., Peri, G., Rizzo, G., Giaccone, A., 2014. On the classification of large 
residential buildings stocks by sample typologies for energy planning purposes. Applied Energy 135, 825-835.

Firth, S.K., Lomas, K.J., Wright, A.J., 2010. Targeting household energy-efficiency measures using sensitivity analysis. Building Research \& Information 38, 25-41.

Gui, X.-c., Ma, Y.-t., Chen, S.-q., Ge, J., 2018. The methodology of standard building selection for residential buildings in hot summer and cold winter zone of China based on architectural typology. Journal of Building Engineering 18, 352-359.

251 Guo, S., Yan, D., Peng, C., Cui, Y., Zhou, X., Hu, S., 2015. Investigation and analyses 252 of residential heating in the HSCW climate zone of China: Status quo and key features. 253 Building and Environment 94, Part 2, 532-542.

254 Happle, G., Fonseca, J.A., Schlueter, A., 2018. A review on occupant behavior in urban 255 building energy models. Energy and Buildings 174, 276-292.

256 Heeren, N., Jakob, M., Martius, G., Gross, N., Wallbaum, H., 2013. A component based 257 bottom-up building stock model for comprehensive environmental impact assessment 258 and target control. Renewable and Sustainable Energy Reviews 20, 45-56.

259 Hong, L., Zhou, N., Feng, W., Khanna, N., Fridley, D., Zhao, Y., Sandholt, K., 2016 . 260 Building stock dynamics and its impacts on materials and energy demand in China. 261 Energy Policy 94, 47-55.

262 Hong, T., Taylor-Lange, S.C., D’Oca, S., Yan, D., Corgnati, S.P., 2016b. Advances in 263 research and applications of energy-related occupant behavior in buildings. Energy and 264 Buildings 116, 694-702.

265 Hu, S., Yan, D., Guo, S., Cui, Y., Dong, B., 2017. A survey on energy consumption and 266 energy usage behavior of households and residential building in urban China. Energy 267 and Buildings 148, 366-378.

268 Huang, J., Wu, J., 2016. Housing Demolition and its Determinants in Urban China. 269 Statistical Research 33, 30-35.

270 IBPSA. Building Energy Software Tools. 2018; 271 http://www.buildingenergysoftwaretools.com/ (accessed 2018.6.12)

272 IEA, 2017. Key world energy statistics.

273 IPCC, 2006. 2006 IPCC Guidelines for National Greenhouse Gas Inventories. 
IPCC, 2014. CLIMATE CHANGE 2014 Synthesis Report-Headline statements from the Summary for Policymakers.

Isaac, M., van Vuuren, D.P., 2009. Modeling global residential sector energy demand for heating and air conditioning in the context of climate change. Energy Policy 37, 507-521.

Jentsch, M.F., James, P.A.B., Bourikas, L., Bahaj, A.S., 2013. Transforming existing weather data for worldwide locations to enable energy and building performance simulation under future climates. Renewable Energy 55, 514-524.

Kavgic, M., Mavrogianni, A., Mumovic, D., Summerfield, A., Stevanovic, Z., Djurovic-Petrovic, M., 2010. A review of bottom-up building stock models for energy consumption in the residential sector. Building and Environment 45, 1683-1697.

Kragh, J., Wittchen, K.B., 2014. Development of two Danish building typologies for residential buildings. Energy and Buildings 68, Part A, 79-86.

Li, B., Yao, R., 2012. Building energy efficiency for sustainable development in China: challenges and opportunities. Building Research \& Information 40, 417-431.

Li, B., Yao, R., Wang, Q., Pan, Y., 2014. An introduction to the Chinese Evaluation Standard for the indoor thermal environment. Energy and Buildings 82, 27-36.

Li, X., Yao, R., Liu, M., Costanzo, V., Yu, W., Wang, W., Short, A., Li, B., 2018. Developing urban residential reference buildings using clustering analysis of satellite images. Energy and Buildings 169, 417-429.

Lin, B., Liu, H., 2015. A study on the energy rebound effect of China's residential building energy efficiency. Energy and Buildings 86, 608-618.

Liu, H., Kojima, S., 2017. Evaluation on the Energy Consumption and Thermal Performance in Different Residential Building Types During Mid-season in Hotsummer and Cold-winter Zone in China. Procedia Engineering 180, 282-291.

Liu, H., Wu, Y., Li, B., Cheng, Y., Yao, R., 2017. Seasonal variation of thermal sensations in residential buildings in the Hot Summer and Cold Winter zone of China. Energy and Buildings 140, 9-18.

Liu, X., Qiu, W., Zhang, H., 2014. Energy Consumption of Residential under Existing Real State in Chongqing Area. Refrigeration and Air Conditioning, 623-627. 
Mastrucci, A., Pérez-López, P., Benetto, E., Leopold, U., Blanc, I., 2017. Global sensitivity analysis as a support for the generation of simplified building stock energy models. Energy and Buildings 149, 368-383.

MOF. The Ministry of Finance of the People's Republic of China announcement No. 18 of 2018.2018 ; http://gks.mof.gov.cn/guozaiguanli/gzfxzjs/201802/t20180207_2810146.html (accessed 2018.10.12)

MOHURD, 2001. Design standard for energy efficiency of residential buildings in hot summer and cold winter zone JGJ 134-2001 (in Chinese). Ministry of Housing and Urban-Rural Development, People's Republic of China.

MOHURD, 2005. Code for design of civil buildings GB 50352-2005. Ministry of Housing and Urban-Rural Development, People's Republic of China.

MOHURD, 2009. Standard for energy efficiency test of residential buildings JGJ/T 132-2009.

MOHURD, 2010. Design standard for energy efficiency of residential buildings in hot summer and cold winter zone JGJ 134-2010 (in Chinese). Ministry of Housing and Urban-Rural Development, People's Republic of China.

MOHURD, 2011. Code for design of residential buildings GB 50096-2011. Ministry of Housing and Urban-Rural Development, People's Republic of China.

MOHURD. The 12th five year plan - building energy saving special planning. 2012a; http://www.gov.cn/zwgk/2012-05/31/content_2149889.htm (accessed 2018.4.29)

MOHURD, 2012b. Evaluation standard for indoor thermal environment in civil buildings GB/T 50785-2012.

MOHURD, 2013a. Minimum allowable values of the energy efficiency and energy efficiency grades for variable speed room air conditioners GB 21445-2013. Ministry of Housing and Urban-Rural Development, People's Republic of China.

MOHURD, 2013b. Standard for lighting design of buildings GB 50034-2013. Ministry of Housing and Urban-Rural Development, People's Republic of China.

MOHURD. Building Energy Conservation and Green Building Development 13th Five Year Plan. 2017; http://www.mohurd.gov.cn/wjfb/201703/t20170314_230978.html 
Monteiro, C.S., Pina, A., Cerezo, C., Reinhart, C., Ferrão, P., 2017. The Use of Multidetail Building Archetypes in Urban Energy Modelling. Energy Procedia 111, 817-825.

MOST. "Green Building and Building Industrialization" Key Project 2016 Application Guide. 2016; http://service.most.gov.cn/sbzn/20160222/885.html (accessed 2017.12.28)

National Development and Reform Commission. Notice from the national development and reform commission on launching the pilot work of low carbon provinces and low carbon cities.

2010 http://www.ndrc.gov.cn/zcfb/zcfbtz/201008/t20100810_365264.html_ (accessed 2018.5.19)

NBS, 2010. Tabulation on the 2010 Population Census of People's Republic of China. China Statistics Press, Beijing.

NBS. Consumer price index. 2018; http://data.stats.gov.cn/easyquery.htm?cn=C01\&zb=A0901\&sj=2016 （accessed 2018.10.12)

NCSC, 2014. Average Carbon Dioxide Emission Factor for China's Regional Power Grid in 2011 and 2012. National center for climate change strategy and international cooperation.

Paone, A., Bacher, J.-P., 2018. The Impact of Building Occupant Behavior on Energy Efficiency and Methods to Influence It: A Review of the State of the Art. Energies 11.

Peng, C., Jiang, Y., 2015. Roadmap for China“s building energy conservation. China Architecture \& Building Press, Beijing.

People's Daily. Southern China is cold and humid in winter, $80 \%$ of netizen support central heating. 2013; http://politics.people.com.cn/n/2013/0108/c100120124969.html (accessed 2016.11.17)

Qi, F., Wang, Y., 2014. A new calculation method for shape coefficient of residential building using Google Earth. Energy and Buildings 76, 72-80.

Reinhart, C.F., Davila, C.C., 2016. Urban building energy modeling - A review of a nascent field. Building and Environment 97, 196-202. 
Royapoor, M., Roskilly, T., 2015. Building model calibration using energy and environmental data. Energy and Buildings 94, 109-120.

SCC, 2016. Integrated Work Program for Energy Conservation in the Thirteenth Five year Plan. the State Council of the People's Republic of China.

SERG. Climate Change World Weather File Generator for World-Wide Weather Data CCWorldWeatherGen. 2017; http://www.energy.soton.ac.uk/ccworldweathergen/ (accessed 2018.03.13)

Shen, L., Wu, Y., Lou, Y., Zeng, D., Shuai, C., Song, X., 2018. What drives the carbon emission in the Chinese cities? - A case of pilot low carbon city of Beijing. Journal of Cleaner Production 174, 343-354.

Shimoda, Y., Asahi, T., Taniguchi, A., Mizuno, M., 2007. Evaluation of city-scale impact of residential energy conservation measures using the detailed end-use simulation model. Energy 32, 1617-1633.

Shimoda, Y., Fujii, T., Morikawa, T., Mizuno, M., 2004. Residential end-use energy simulation at city scale. Building and Environment 39, 959-967.

Shimoda, Y., Yamaguchi, Y., Okamura, T., Taniguchi, A., Yamaguchi, Y., 2010. Prediction of greenhouse gas reduction potential in Japanese residential sector by residential energy end-use model. Applied Energy 87, 1944-1952.

Sokol, J., Cerezo Davila, C., Reinhart, C.F., 2017. Validation of a Bayesian-based method for defining residential archetypes in urban building energy models. Energy and Buildings 134, 11-24.

State Council. Work plan for controlling greenhouse gas emissions during the "thirteenth five-year plan". 2016; http://www.gov.cn/zhengce/content/201611/04/content_5128619.htm (accessed 2018.5.14)

State Council. Chongqing. 2017; http://www.gov.cn/guoqing/201801/15/content_5256794.htm (accessed 2018.1.12)

Stephan, A., Stephan, L., 2016. Life cycle energy and cost analysis of embodied, operational and user-transport energy reduction measures for residential buildings. Applied Energy 161, 445-464.

Swan, L.G., Ugursal, V.I., 2009. Modeling of end-use energy consumption in the 
residential sector: A review of modeling techniques. Renewable and Sustainable Energy Reviews 13, 1819-1835.

TABULA. TABULA Building Typologies - Country Pages. 2016; http://episcope.eu/building-typology/country/ (accessed 2017.11.15)

Tardioli, G., Kerrigan, R., Oates, M., O‘Donnell, J., Finn, D., 2015. Data Driven Approaches for Prediction of Building Energy Consumption at Urban Level. Energy Procedia 78, 3378-3383.

THUBERC, 2015. Annual Report on China Building Energy Efficiency. China Architecture \& Building Press, Beijing.

THUBERC, 2016. Annual Report on China Building Energy Efficiency. China Architecture \& Building Press, Beijing.

THUBERC, 2017. Annual Report on China Building Energy Efficiency. China Architecture \& Building Press, Beijing.

UN, 2014. World Urbanization Prospect 2014 Revision. United Nations, New York.

Wang, B., Xia, X., Zhang, J., 2014. A multi-objective optimization model for the lifecycle cost analysis and retrofitting planning of buildings. Energy and Buildings 77, $227-$ 235.

Wang, N., Makhmalbaf, A., Srivastava, V., Hathaway, J.E., 2016. Simulation-based coefficients for adjusting climate impact on energy consumption of commercial buildings. Building Simulation 10, 309-322.

Wang, Z., 2017. Research on Demand and Suitable Terminal for Housing Heating in Hot-Summer-Cold-Winter Climate Region of China, Architecture. Tsinghua University, Beijing.

Wang, Z., Zhao, Z., Lin, B., Zhu, Y., Ouyang, Q., 2015. Residential heating energy consumption modeling through a bottom-up approach for China's Hot Summer-Cold Winter climatic region. Energy and Buildings 109, 65-74.

Wei, C., Huang, Y., Guo, J., 2014. Competition between north and south heating: research based on household questionnaire data.

Wilson, E., Christensen, C., Horowitz, S., Horsey, H., 2016. A high-granularity approach to modeling energy consumption and savings potential in the U.S. residential 

building stock, ASHRAE and IBPSA-USA SimBuild 2016, Building Performance Modeling Conference, Salt Lake City, UT.

Xu, L., Liu, J., Pei, J., Han, X., 2013. Building energy saving potential in Hot Summer and Cold Winter (HSCW) Zone, China-Influence of building energy efficiency standards and implications. Energy Policy 57, 253-262.

Xu, P., Shen, Y., Chen, L., Mao, J., Chang, E., Ji, Y., 2015. Assessment of energy-saving technologies retrofitted to existing public buildings in China. Energy Efficiency, 1-28.

Yang, W., Kohler, N., 2007. Simulation of the evolution of the Chinese building and infrastructure stock. Building Research \& Information 36, 1-19.

Yao, R., Costanzo, V., Li, X., Zhang, Q., Li, B., 2018. The effect of passive measures on thermal comfort and energy conservation. A case study of the hot summer and cold winter climate in the Yangtze River region. Journal of Building Engineering 15, 298310.

Yi, H., Srinivasan, R.S., Braham, W.W., 2015. An integrated energy-emergy approach to building form optimization: Use of EnergyPlus, emergy analysis and Taguchiregression method. Building and Environment 84, 89-104.

Yu, S., Eom, J., Evans, M., Clarke, L., 2014a. A long-term, integrated impact assessment of alternative building energy code scenarios in China. Energy Policy 67, 626-639.

Yu, S., Evans, M., Shi, Q., 2014b. Analysis of the Chinese market for building energy efficiency. Pacific Northwest National Laboratory (PNNL), Richland, WA (US).

Zhao, S., Feng, W., Zhang, S., Hou, J., Zhou, N., Levine, M., 2015. Energy Savings and Cost-benefit Analysis of the New Commercial Building Standard in China. Procedia Engineering 121, 317-324.

Zheng, X., Wei, C., Qin, P., Guo, J., Yu, Y., Song, F., Chen, Z., 2014. Characteristics of residential energy consumption in China: Findings from a household survey. Energy Policy 75, 126-135. 